\title{
Screening and Druggability Analysis of Some Plant Metabolites against SARS-CoV-2
}

Kazi Faizul Azim, ${ }^{\text {a,b }}$ Sheikh Rashel Ahmed, ${ }^{\text {a,c* }}{ }^{*}$ Anik Banik, ${ }^{a}$ Md. Mostafigur Rahman Khan, ${ }^{a}$ Anamika Deb ${ }^{\mathrm{a}}$

${ }^{a}$ Faculty of Biotechnology and Genetic Engineering, Sylhet Agricultural University, Sylhet3100, Bangladesh;

${ }^{b}$ Department of Microbial Biotechnology, Sylhet Agricultural University, Sylhet-3100, Bangladesh;

${ }^{c}$ Department of Plant and Environmental Biotechnology, Sylhet Agricultural University, Sylhet-3100, Bangladesh;

Abbreviations: CoV, Corona virus; SARS, Severe acute respiratory syndrome; Middle East respiratory syndrome; Nsp, Non-structural protein; LD50, Lethal dose 50; ADME, Absorption, distribution, metabolism, and excretion; BBB, Blood brain barrier

\section{*Corresponding author:}

\section{Sheikh Rashel Ahmed}

Assistant Professor and Chairman, Department of Plant \& Environmental Biotechnology, Sylhet Agricultural University, Sylhet-3100,Bangladesh

E-mail: rashel.peb@sau.ac.bd

Phone: +8801925652984 


\begin{abstract}
$\underline{\text { ABSTRACT }}$
The sudden outbreak of novel corona virus at the end of 2019 has caused a global threat to mankind due to its extreme infection rate and mortality. Despite extensive research, still there is no an approved drug or vaccine to combat SARS-CoV-2 infections. Hence, the study was designed to evaluate some plant-based active compounds for drug candidacy against SARS-CoV-2 by using virtual screening methods and various computational analysis. A total of 27 plant metabolites were screened against SARS-Cov2 main protease proteins (MPP), Nsp9 RNA binding protein, spike receptor binding domain, spike ecto-domain and HR2 domain using molecular docking approach. Four metabolites i.e. asiatic acid, avicularin, guajaverin and withaferin showed maximum binding affinity with all key proteins in terms of lowest global binding energy. The top candidates were further employed for ADME (absorption, distribution, metabolism, and excretion) analysis to investigate their drug profiles. Results suggest that none of the compounds render any undesirable consequences that could reduce their drug likeness properties. The analysis of toxicity pattern revealed no significant tumorigenic, mutagenic, irritating or reproductive effects by the compounds. However, witheferin was comparatively toxic among the top four candidates with considerable cytotoxicity and immunotoxicity. Most of the target class by top drug candidates belonged to enzyme groups (e.g. oxidoreductases hydrolases, phosphatases). Moreover, results of drug similarity prediction identified two approved structural analogs of Asiatic acid from DrugBank, Hydrocortisone (DB00741) (previously used for SARS-CoV-1 and MERS) and Dinoprost-tromethamine (DB01160). In addition, two other biologically active compounds, Mupirocin (DB00410) and Simvastatin (DB00641) could be an alternative choice to witheferin for the treatment of viral infections. The study may pave the way to develop effective medications and preventive measure against SARS-CoV-2 in the future. However, the results were based solely on computational tools and algorithms. Due to the encouraging results, we highly recommend further in vivo trials for the experimental validation of our findings.
\end{abstract}

Keywords: SARS-CoV-2; plant metabolites; main protease proteins; molecular docking; ADME analysis; drug target 


\section{Introduction}

The sudden outbreak of novel corona virus (SARS-CoV-2) infection, which caused a worldwide anxiety, emanated from Wuhan, China at the end of 2019 and spread over all around the world except few countries (Yao et al., 2020). The virus is responsible for causing this novel corona disease, which WHO officially called COVID-19. As of April 23, 2020, World Health Organization (WHO) estimated that new Corona virus infected more than 30 lacs confirmed cases of peoples, caused death of over two lac and thirty thousand, touched 215 countries, areas or territories (WHO, 2020) and its infection rate is increasing day by day at alarming rate that could pose a global threat to mankind (Zhou et al., 2020a). The fatality rate of SARS-CoV-2 (3.4\%) is estimated by WHO, which is lower than previous fatal diseases SARS and MERS having death rates of $9.6 \%$ \& 35\%, respectively (Guo et al., 2020; de Wit et al., 2016).

Coronaviruses are enveloped, positive single-stranded RNA viruses with large genome size ranging from $26 \mathrm{~kb}$ to $32 \mathrm{~kb}$. These viruses are the representative of four subfamilies, which include alpha-, beta-, gamma- and delta- Corona viruses. COVID-19 has more sequence similarity with SARS-CoV than MERS CoV when genome sequences of these mentioned viruses have been compared (Chan et al., 2020), but also have dissimilarities that can influence their process of pathogenesis (Kannan et al., 2020; Mousavizadeh and Ghasemi, 2020). 2019-nCoV infect human through same entry point of ACE receptor, expressing in respiratory tract (Zhou et al., 2020b; Wan et al., 2020). However, among various proteins, four proteins are commonly found in the structure of all coronavirus representing spike $(\mathrm{S})$, envelope(E), membrane(M), and nucleocapsid (N) (Mousavizadeh and Ghasemi, 2020). The initial and important stage of viral entry into host cell is receptor recognition $(\mathrm{Li}, 2015)$. The assembly of viral particle occurred by membrane protein $(\mathrm{M})$ and envelope protein $(\mathrm{E})$ whereas, virus binding and entrance into host cell took place by spike protein (S) with the assistance of SARS-CoV angiotensin-converting enzyme (Li, 2016; Wan et al., 2020).

New Corona viruses (SARS-CoV-2), belonging to Beta-coronaviruses, are responsible for causing severe human respiratory syndrome (Velavan and Meyer, 2020; Zhou et al., 2020a). The virus is spread mainly through the community transmission, on the other hand, SARS and MERS affected other peoples through nosocomial spread (Munster et 
al., 2020). It can transmit from one individual to other by respiratory droplets. The general sign and symptoms of SARS-CoV-2 infected patients suffered from initially with common flu-like fever, Sputum production, Dyspnoea, Headache, Sore throat/Pharyngalgia, Diarrhoea etc and further leads to express life threatening symptoms of unusual fatal pneumonia (Zheng, 2020). However, COVID19 affected patients, either symptomatic or asymptomatic, were detected with the nose containing higher viral load than in the throat (Zou et al., 2020). A critically ill patient has to fall into a series of complexity with progression of disease.

The efficacy and safety of antivirals required to be evaluated by continuous clinical trials (Zhou et al., 2020a). There has no efficient, safe and specific potential therapeutics has been approved for rapid remedy of this new respiratory syndrome ( $\mathrm{Lu}, 2020$; $\mathrm{Li}$ and $\mathrm{De}$ Clercq, 2020). Though, clinical trials of some drugs for Corona treatment have been started, till now, a few candidates have shown their efficacy in in vitro studies, not many have progressed to randomized animal or human trials, hence may have limited use to counter infection (Dhama et al., 2020). Many countries, pharmaceutical company announced their headway and program to develop vaccines (e.g. subunit, mRNA, DNA, live-vector vaccine) against the virus. But, the developmental process of making human vaccine from concept to licensure may take a couple of years to limit the global emergency need (Bregu et al., 2011). As the epidemic is still spreading, medicinal plants may be alternative to be used in making drugs as early as possible. Several scientific researchers reported the necessity of plant as medicinal value and therapeutic uses as drugs from ancient times (Suheda et al., 2015). Plant-derived active compounds of different plant part are useful for treating diseases including diarrhoea, headache, and inflammation, bacterial and fungal infections. From prehistoric times, traditional peoples utilized these for the remedial purposes of health deteriorating diseases because of its existence of numerous phytochemicals (Kumar et al., 2019). Various limitations are associated with modern treatment options including drug-resistance, severe side effects, adverse toxicity profiles, complicated medication administration of. Natural products have the potential to form the basis of holistic health care (Cheuka et al., 2016). The properties of antioxidant render medicinal plants to be effective in treating lifethreatening diseases (e.g. cancer, Alzheimer, diabetes, cardiac disease) (Table 1) and also minimize drug toxicity (Karimi et al., 2015). 
The expansion of natural product as new medicine or drug to resist the emerging virus SARS-CoV-2 could be done to bypass the side effect of synthetic drugs. Therefore, the study aimed at evaluating some plant-based active compound for drug candidacy against SARS-CoV-2 through virtual screening methods and various computational investigations.

\section{Materials and Methods}

\subsection{Retrieval of SARS-CoV-2 proteins/protein-domains and plant metabolites}

The 3D structures of SARS-Cov-2 main proteases (6W63, 6LU7), Nsp9 (Non-structural protein-9) RNA binding protein (6W4B), Spike receptor binding domain (6M0J), spike ecto-domain (6VYB), and HR2 Domain $(6 \mathrm{LVN})$ were retrieved from the RCSB Protein Data Bank (Rose et al., 2017). A total of 27 plant metabolites belonging to different classes were extracted from PubChem database (https://pubchem.ncbi.nlm.nih.gov/)(Kim et al., 2016) in SDS (3D) format (Table 1). The structures were further converted into PDB format by OpenBabel v2.3 software (O'Boyle et al., 2011).

\subsection{Screening of plant metabolites against SARS-CoV-2 proteins/protein-domains}

Molecular docking is an effective approach for screening out the suitable therapeutics against specific drug target of deadly pathogens (Meng et al., 2011). This powerful tool is used to model the interaction between small ligands and macromolecules, thereby can pave the way for drug discovery (Kitchen et al., 2004). The binding affinity of 27 plant metabolites with different SARS-CoV-2 proteins/prorein domains (drug targets/macromolecules) were determined by using PatchDock server (SchneidmanDuhovny et al., 2005). Recently, alpha-ketoamide (CID 6482451) has been suggested as aSARS-CoV-2 main proteaseprotein inhibitorby experimental study (Zhang et al., 2020). The ligand was used as positive control for the present study and employed to docking analysis against all six macromolecules. The docked complexes were further refined via FireDock refinement tool (Mashiach et al., 2008). The ligand binding complexes were visualized by Discovery Studio v3.1 (Wanget al., 2015) and PyMOL v2.0 (DeLano, 2002). 


\subsection{Drug profile analysis of top metabolites}

Absorption, distribution, metabolism, and excretion (ADME) are four major criteria that influence the drug levels and kinetics of drug exposure to the tissues within an organism. The pharmacological activity and performance of a drug is largely controlled bythese parameters (Balani et al., 2005). SwissADME server was used (Daina et al., 2017) to assess the absorption, distribution, metabolism and excretion properties of the top four metabolites. BOILED-Egg model was employed to calculate the Blood-brain barrier (BBB) in the studied compounds (Daina and Zoete, 2016). The relative toxicity of top drug candidates were predicted via ProToxII server (Banerjee et al., 2018). The server incorporates molecular similarity, fragment propensities and fragment similarity based CLUSTER cross-validation based a total of 33 models for the prediction of various toxicity endpoints. Additionally, OSIRIS Property Explorer were employed to investigate the undesired effects of these compounds (Sander, 2001).

\subsection{Prediction of drug targets and available drug molecules from DrugBank}

SwissTargetPrediction was used to estimate the probable macromolecular targets of predicted drug candidates (Daina et al., 2019). The server predicts based on a combination of 2D and 3D similarity with a library of 370000 known bioactive compounds on approximately 3000 proteins. Moreover, SwissSimilarity web tools were used to identify potential drug molecules against SARS-CoV-2 based on homology screening of predicted top drug candidates. Theserver allowed ligand-based virtual screening of several libraries of small molecules to find lapproved, experimental or commercially available drugs from DrugBank using different approaches including FP2 fingerprints, electroshape, spectrophores and align-IT (Zoete et al., 2016).

\section{Results}

\subsection{Screening of plant metabolites against SARS-CoV-2}

All of the retrieved structures ofSARS-CoV-2 proteins/protein-domains (macromolecules) and plant metabolites (ligands)were optimized and employed for molecular docking to predict the affinity between above mentioned ligands and the 
macromolecules. The metabolites were ranked based on global binding energy and the results depict that top four scorers(metabolites) were same for each of the macromolecules in terms of minimum binding energy (Table 2 and Supplementary File 1). In each case, asiatic acid, avicularin, guajaverin andwithaferin showed best binding interactions with six studied macromolecules (Figure 1 and Table 2). Moreover, asiatic acid showed highest binding affinity with SARS-CoV-2 main protease $(-53.05 \mathrm{kcal} / \mathrm{mol})$, Nsp9 RNA binding protein $(-50.04 \mathrm{kcal} / \mathrm{mol})$ and spike ecto-domain $(60.68 \mathrm{kcal} / \mathrm{mol})$ (Figure 2 and Table 2), while guajaverinbound with spike receptor binding domain and HR2 Domain with a binding energy of $-47.34 \mathrm{kcal} / \mathrm{mol}$ and $-28.73 \mathrm{kcal} / \mathrm{mol}$, respectively (Figure 3 and Table 2).

\section{2. $A D M E$ analysis of top drug candidates}

Different ADME properties i.e. physicochemical parameters, pharmacokinetics, lipophilicity, water solubility, medicinal chemistry of top drug candidates were estimated to evaluate their drug profiles (Figure 4 and Table 3). Analysis of inhibition effectswith different CYP isoforms (CYP1A2, CYP2D6, CYP2C9, CYP2C19, CYP3A4) revealed that none of the candidates had such interaction possibility with any cytochromes P450 isoforms. GI absorption was found higher for asiatic acid and witheferin, while lower for guajaverin and avicularin. Moreover, blood-brain barrier (BBB) permeation was calculated by BOILED-Egg model which revealed no BBB permeantamong the studied top drug candidates. Each candidate were water soluble from a moderate to high level, while guajaverin and avicularin showed maximum solubility (Table 3).

\subsection{Toxicity pattern analysis of top drug candidates}

Prediction of various toxicity endpoints such as acute toxicity, hepatotoxicity, cytotoxicity, carcinogenicity, mutagenicity, immunotoxicity, adverse outcomes (Tox21) pathways and toxicity targets were analysed (Table 4). Results revealed that guajaverin and avicularin fell in the category of toxicity class 5 , while the predicted toxicity group for Asiatic acid and witheferin were 4 and 2 respectively (the lower the class the higher the toxicity).Estimated LD50 for asiatic acid, avicularin, guajaverin and withaferin were 2000, 5000, 5000 and $7 \mathrm{mg} / \mathrm{kg}$ respectively. The toxicity radar in Figure 5 illustrates the confidence of positive toxicity results compared to the average of its class. None of the 
compounds showed any undesired effects such as tumorigenicity, mutagenicity, irritating or reproductive effects. Witheferin, however, found to be relatively toxic among the four candidates with considearble cytotoxicity and immunotoxicity (Figure 5).

\subsection{Prediction of drug targets and available drug molecules from DrugBank}

Most of the target class belonged to enzymes, kinase proteins, oxidoreductases (i.e. aldose reductase, aldo-keto reductase), phosphatasesand lyases (i.e. carbonic anhydrase) (Figure 6 and Table 5).Ligand-based virtual screening was performedto predict biologically active small compounds against SARS-CoV-2 from DrugBank.Two approved drugs, Hydrocortisone (DB00741) and Dinoprost-tromethamine (DB01160) were found analogous to asiatic acid with prediction score 50.52 and 50.53 respectively.Moreover, results revealed the similarity of Mupirocin (DB00410) and Simvastatin (DB00641) with witheferin with high prediction score (Table 6). The findingssuggest that these could be potential drug candidates against SARS-CoV-2, thus require further experimental trials.

\section{Discussion}

Excessive infection rates and mortality of SARS-CoV-2 led the researchers to concentrate immensely on developing strategies for combating infections caused by it (Wilder-Smith et al., 2020; Yuen et al., 2020; Lake, 2020). Regardless of praiseworthy initiative, still there is no approved drugs or vaccine that could treatSARS-CoV-2infected patients (Fang et al., 2020; Prompetchara et al., 2020). Though some candidates are in the investigational stages, many of them raised controversy issues (Zhou et al., 2020; Dong et al., 2020). Plant-derived natural products play a significant role by being a lead molecule in the development of drug candidates (Josephet al., 2017). Hence, in the present study, attempts were taken to evaluate some plant derived metabolites as an inhibitory agent of SARS-CoV-2 based on their binding affinities to the key proteins of the pathogen.

The contribution by computational biology has accelerated the pace of drug discovery. It is used in the biopharmaceutical industry to discover and develop new lead compounds. By this route, one can visualize the possibilities of binding of potential small molecules as ligands/inhibitors (Josephet al., 2017). Phytomolecules like Baicalein, Luteolin, 
Quercetin and Kaempferol are potential antiviral agents against a wide range of important viruses including Dengue, HIV, H5N1 influenza A virus, Coxsackie virus, CHIKV and Japanese encephalitis virus(Habbu et al., 2009). Recent studies focused on MPP inhibitors of SARS-CoV-2 i.e. alpha-ketoamide, Hydroxy, Remdesivir, Chloroquine and Favipiravir to evaluate their potency as drug (Al-Tawfiq et al., 2020; Colson et al., 2020). Several in silicostrategies were also adopted to screen putative drug candidates against SARS-CoV-2 (Parvez et al., 2020; Hasan et al., 2020). However, all these experiments used either main protease proteins or RNA-dependent RNA polymerase of SARS-CoV2as probable drug targets. In this study, we screenedsome naturalmetabolites against SARS-Cov-2 main proteases (6W63, 6LU7), Nsp9 (Non-structural protein-9) RNA binding protein $(6 \mathrm{~W} 4 \mathrm{~B})$, spike receptor binding domain $(6 \mathrm{M} 0 \mathrm{~J})$, spike ecto-domain (6VYB), and HR2 domain (6LVN) using molecular docking approach (Chang et al., 2010; Hasan et al., 2019). The polyproteins of coronavirus are cleaved and transformed in mature non-structural proteins (NSPs) by proteases (Hilgenfeld, 2014).As a putative component in the replication complex, nsp9 may possibly have an RNA binding activity. Viral replication complexes are frequently membrane associated and nsp9 helps in this case. The entry of coronavirus into host cells, on the other hand, is mediated by the transmembrane spike glycoprotein that forms homotrimers protruding from the viral surface. S protein comprises two functional subunits responsible for binding to the host cell receptor $\left(S_{1}\right)$ and fusion of the viral and cellular membranes $(S)$. After the attachment of the receptor-binding subunit to the receptor, the HR1 and HR2 domains in the membrane fusion subunit interact with each other and form a six-helix bundle and this conformational change results in a close apposition of the fusion peptide leading to viruscell membrane fusion (Moore et al., 2003). Thus, all these proteins represent an attractive pharmacological target for SARS-CoV-2.

Results revealed that asiatic acid had highest binding affinity with SARS-CoV-2 main protease $(-53.05 \mathrm{kcal} / \mathrm{mol})$, Nsp9 RNA binding protein $(-50.04 \mathrm{kcal} / \mathrm{mol})$ and spike ectodomain (60.68 kcal/mol) (Figure 2 and Table 2). Remarkably, four metabolitesi.e. asiatic acid, avicularin, guajaverin and withaferin scored best for eachsix macromolecules and bound with minimum global binding energy (Table 2 and Supplementary File 1). Most importantly, the scores of top most candidates were either close or in some instances lower than alpha ketoamide, a positive control used in the present study (Table 2).Asiatic acid, a triterpenoid derivative from Centella asiatica, has displayed antioxidative, anti- 
inflammatory, and protective properties against neurotoxicity induced by glutamate- or bamyloid-induced (Krishnamurthy et al., 2009). Bian et al. (2013) also reported the inhibitory activities of asiatic acid and included in the arsenal for combating against fibroproliferative disorders (Keloids) by blocking TGF- $\beta /$ Smad pathway. Withanolides, nature-derived secondary metabolites, produced in Withania somnifera via oxidation of steroids and have medicinal value anti-inflammation, anti-cancer, adaptogenic and antioxidant effects (Vaishnavi et al., 2012). Withaferin, which is a steroidal lactone, suppress HIV-1 LTR transcription and viral replication (Shi et al., 2017) and also have vital function to inhibit Herpes simplex virus (Grover et al., 2011). Ithas anti-inflammatory properties (White et al., 2016) and also showed neuro-protective activity against A $\beta$ neurotoxicity (Tiwari et al., 2018). Molecular docking and simulation study also revealed that it has vital function to attenuate the neuraminidase of H1N1 influenza virus (Cai et al., 2015).

Guaijaverin and Avicularin are the main bioactive components in guava leaves with hypoglycemic properties and inhibitory capacity against free fatty acid release (Wen et al, 2016). The microbicidial activity of is attributable to guajaverine. Anti-plaque activity is attributed to microbicidial activity of guajaverine of $P$. guajava against the growth of the Strep. Mutans, thus becoming an alternative for oral health care (Prabu et al., 2006).Avicularin(quercetin- 3-O- $\alpha$-L-arabinofuranoside), is a flavonoid of plant and glycoside of quercetin, has been suggested to display diverse pharmacological properties such as anti-inflammatory and anti-infectious effects (Vo et al., 2012; Shen et al., 2019). Lee et al. (2019) reported the effective anti-oxidant potentiality of Avicularin from Lespedeza cuneata. Avicularin from Taxillus kaempferi, inhibited the accumulation of the intracellular lipids by reducing glucose uptake in adipocytes, as reported by Fujimori and Shibano (2013). It was one of the principal compounds of $P$. aviculare and has been reported to inhibit pancreatic lipase (PL) (Park et al., 2019). Kim et al. (2011) identified hepatoprotective activity of Avicularin extracted from the aerial parts of Lespedeza cuneataagainst lesion caused by t-BHP in HepG2 cells.It has also been suggested to inhibit activation of ERK signaling pathway through LPS-stimulated overproduction of pro-inflammatory mediators and cytokine (Vo et al., 2012). Shen et al. (2019) investigated anti-depressant like properties of Avicularin on a mouse model of depression, and got relief from chronic unpredictable mild stress (CUMS) induced depressive-like behaviors. Avicularin may also suppress the inflammatory response, and 
causes apoptosis in human RA synovial cells through obstructing the activation of the MEK/NF- $\kappa B$ pathway, thus preventing rheumatoid arthritis (RA) in vitro (Wang et al., 2018).

ADME data, whether experimentally measured or computationally predicted, provide key insights into how a drug will ultimately be treated or accepted by the body. So while a drug lead may exhibit phenomenal efficacy in vitro, poor ADME results will almost invariably terminate its development (Wishart, 2007). Computational methods are playing a key role in anticipating potential ADME and toxicity problems and reducing the number of experiments that involve animal testing obviously.Therefore, the top most drug candidates were employed for ADME analysis to investigate their drug profiles. None of the metabolites, however showed any undesirable consequences that could reduce their drug likeness properties. SARS-CoV-2 appears as asevere acute respiratory disease nor a neuro disease (Astuti et al., 2020), so there is no need to permeate the blood brain barrier (BBB) for being an effective molecule against SARS-CoV-2.However, no BBB permeants were found among the top drug candidates. Most of the target class for the top drug candidates belonged to the categories of enzymes (e.g. oxidoreductases, hydrolase, phosphatases, lyases (Table 5). The major protease proteins (protein hydrolase) of SARS-CoV-2 thus can be a specific target for these natural metabolites. The toxicity of drug impurities is closely related to their structure. Structure-activity relationships (SARs) have been widely used in Europe and the United States to predict toxicity by computer (Guan et al., 2019). The toxicity prediction results from our study revealed negligible tumorigenic, mutagenic, irritating or reproductive effects by the candidates, though witheferin, was found to be comparatively toxic among the top four candidates.

However drug similarity prediction identified two approved structural analogsof witheferin,Mupirocin (DB00410) and Simvastatin (DB00641)which could be an alternative choice, and therefore require further in vivo investigations. Ligand-based virtual screening using Asiatic acid predicted two other biologically active compounds, Hydrocortisone (DB00741) and Dinoprost-tromethamine (DB01160) from DrugBank.Interestingly, Hydrocortisone which is a cortisone based drug, was previously used during SARS-CoV-1 and MERS outbreak(Barzilai et al., 1972). Diosmin, on the contrary, are used as supplementary drug found in various natural plants (Moldovan et al., 2010). Myricetin showed the potential to inhibit reverse transcriptase of RLV and 
HIV virus, while characterized by having antioxidative and prooxidative properties.It is also a potent anticarcinogen and antimutagen (Ong and Khoo, 1997). The most significant finding of this study is Simvastatin, which can block downstream molecules those are key factors in virus infectivity and also can control severe influenza and pneumonia through prevention of excess cytokine release (Jung et al., 2012). The results suggest that all these compounds could be potential drug candidates against SARS-CoV2. However, all of the investigational drugs of SARS-CoV-2 are under strict regulation of World Health Organization. Due to the encouraging results, we highly recommend further in vivotrialsfor theexperimental validation of our findings. The present study may pave the way to develop effective medications and preventive measure against SARS-CoV-2 in the future.

\section{Acknowledgements}

Authors would like to acknowledge the Department of Microbial Biotechnology, Department of Pharmaceuticals and Industrial Biotechnology and Department of Plant and Environmental Biotechnology of Sylhet Agricultural University for the technical support.

\section{Funding information}

This research did not receive any specific grant from funding agencies in the public, commercial, or not-for-profit sectors.

\section{Conflict of interest}

Authors declare that they have no conflict of interests.

\section{References}

Yao TT, Qian JD, Zhu WY, Wang Y, Wang GQ. A systematic review of lopinavir therapy for SARS coronavirus and MERS coronavirus-A possible reference for 
coronavirus disease-19 treatment option [published online ahead of print, $2020 \mathrm{Feb}$ 27]. J Med Virol. 2020;10.1002/jmv.25729. doi:10.1002/jmv.25729

Zhou, M., Zhang, X. \& Qu, J. 2020a. Coronavirus disease 2019 (COVID-19): a clinical update. Front. Med.. https://doi.org/10.1007/s11684-020-0767-8

Zou L, Ruan F, Huang M, Liang L, Huang H, Hong Z, Yu J, Kang M, Song Y, Xia J, Guo Q, Song T, He J, Yen HL, Peiris M, Wu J. SARS-CoV-2 viral load in upper respiratory specimens of infected patients. N Engl J Med 2020 Feb 19. [Epub ahead of print] doi: 10.1056/NEJMc2001737

Munster VJ, Koopmans M, van Doremalen N, van Riel D, de Wit E. A Novel Coronavirus Emerging in China - Key Questions for Impact Assessment. N Engl J Med. 2020;382(8):692-694. doi:10.1056/NEJMp2000929

de Wit E, van Doremalen N, Falzarano D, Munster VJ. SARS and MERS: recent insights into emerging coronaviruses. Nat Rev Microbiol. 2016;14(8):523-34

Guo YR, Cao QD, Hong ZS, Tan YY, Chen SD, Jin HJ et al. The origin, transmission and clinical therapies on coronavirus disease 2019 (COVID-19) outbreak - an update on the status. Mil Med Res. 2020;7(1):11. Published 2020 Mar 13. doi:10.1186/s40779-020-00240-0

Zheng J. SARS-CoV-2: an Emerging Coronavirus that Causes a Global Threat. Int J Biol Sci 2020; 16(10):1678-1685. doi:10.7150/ijbs.45053. Available from http://www.ijbs.com/v16p1678.html

Zhou P, Yang XL, Wang XG, Hu B, Zhang L, Zhang W, Si HR, Zhu Y et al. 2020b. A pneumonia outbreak associated with a new coronavirus of probable bat origin. Nature. 2020b; 579(7798):270-273. doi: 10.1038/s41586-020-2012-7.

Velavan TP, and Meyer CG. 2020. The COVID-19 epidemic. Tropical Medicine and International Health. 25(3):278-280. doi:10.1111/tmi.13383

Mousavizadeh L, Ghasemi S. Genotype and phenotype of COVID-19: Their roles in pathogenesis [published online ahead of print, 2020 Mar 31]. J Microbiol Immunol Infect. 2020;. doi:10.1016/j.jmii.2020.03.022 
Zhang H, Penninger JM., Li Y., Zhong N and Slutsky AS. Angiotensin-converting enzyme 2 (ACE2) as a SARS-CoV-2 receptor: molecular mechanisms and potential therapeutic target. Intensive Care Med 46, 586-590 (2020). https://doi.org/10.1007/s00134-020-05985-9

Kannan S, Shaik Syed Ali P, Sheeza A, Hemalatha K. COVID-19 (Novel Coronavirus 2019) - recent trends. Eur Rev Med Pharmacol Sci. 2020;24(4):2006-2011. doi:10.26355/eurrev_202002_20378

Wan Y, Shang J, Graham R, Baric RS, Li F. Receptor recognition by novel coronavirus from Wuhan: An analysis based on decade-long structural studies of SARS. J Virol. 2020;JVI.00127-20; Epub ahead of print.

Velavan TP and Meyer CG. 2020. The COVID-19 epidemic. Tropical Medicine and International Health 25(3): 278-280. doi:10.1111/tmi.13383

Li F. 2015. Receptor recognition mechanisms of coronaviruses: a decade of structural studies. J Virol 89:1954 -1964. doi:10.1128/JVI.02615-14.

Li F. Structure, Function, and Evolution of Coronavirus Spike Proteins. Annu Rev Virol. 2016;3(1):237-261. doi:10.1146/annurev-virology-110615-042301

Bregu M, Draper SJ, Hill AV, Greenwood BM. Accelerating vaccine development and deployment: report of a Royal Society satellite meeting. Philos Trans R Soc Lond B Biol Sci. 2011;366(1579):2841-2849. doi:10.1098/rstb.2011.0100

Dhama K, Sharun K, Tiwari R, Dadar M, Malik YS, Singh KP \& Chaicumpa W (2020). COVID-19, an emerging coronavirus infection: advances and prospects in designing and developing vaccines, immunotherapeutics, and therapeutics, Human Vaccines \& Immunotherapeutics, DOI: 10.1080/21645515.2020.1735227

Lu, H. "Drug treatment options for the 2019-new coronavirus (2019-nCoV)," Biosci. Trends, 2020, doi:10.5582/bst.2020.01020.

Li G, De Clercq E. Therapeutic options for the 2019 novel coronavirus (2019-nCoV). Nat Rev Drug Discov. 2020;19(3):149-150. doi:10.1038/d41573-020-00016-0 
Kumar, V., Suri, S., Prasad, R., Gat Y, Sangma C, Jakhu H andSharma M. Bioactive compounds, health benefits and utilization of Rhododendron: a comprehensive review. Agric \& Food Secur 8, 6 (2019). https://doi.org/10.1186/s40066-019-0251-3

Suheda Koc, Belgin S. Isgor, Yasemin G. Isgor, Naznoosh Shomali Moghaddam \& Ozlem Yildirim (2015) The potential medicinal value of plants from Asteraceae family with antioxidant defense enzymes as biological targets, Pharmaceutical Biology, 53:5, 746-751, DOI: 10.3109/13880209.2014.942788

Cheuka PM, Mayoka G, Mutai P, Chibale K. The Role of Natural Products in Drug Discovery and Development against Neglected Tropical Diseases. Molecules. 2016;22(1):58. Published 2016 Dec 31. doi:10.3390/molecules22010058

El-Saber Batiha, G., Magdy Beshbishy, A., G Wasef, L., Elewa, Y., A Al-Sagan, A., Abd El-Hack, M. E., Taha, A. E., M Abd-Elhakim, Y., \& Prasad Devkota, H. (2020). Chemical Constituents and Pharmacological Activities of Garlic (Allium sativum L.): A Review. Nutrients, 12(3), 872. https://doi.org/10.3390/nu12030872

Mussard E, Cesaro A, Lespessailles E, Legrain B, Berteina-Raboin S, Toumi H. Andrographolide, a Natural Antioxidant: An Update. Antioxidants (Basel). 2019; 8(12):571. doi:10.3390/antiox 8120571

Salehi B., Venditti A., Sharifi-Rad M., Kręgiel D., Sharifi-Rad J., Durazzo A., Lucarini M., Santini A., Souto E. B., Novellino E., Antolak H., Azzini E., Setzer W. N., \& Martins N. (2019). The Therapeutic Potential of Apigenin. International journal of molecular sciences, 20(6), 1305. https://doi.org/10.3390/ijms20061305

Nagoor Meeran MF, Goyal SN, Suchal K, Sharma C, Patil CR, Ojha SK. Pharmacological Properties, Molecular Mechanisms, and Pharmaceutical Development of Asiatic Acid: A Pentacyclic Triterpenoid of Therapeutic Promise. Front Pharmacol. 2018; 9:892. Published 2018 Sep 4. doi:10.3389/fphar.2018.00892

Wang Z, Li F, Quan Y, Shen J. Avicularin ameliorates human hepatocellular carcinoma via the regulation of NF- $\kappa \mathrm{B} / \mathrm{COX}-2 / \mathrm{PPAR}-\gamma$ activities. Molecular medicine reports. 2019 Jun 1;19(6):5417-23. 
Hayman M, Kam P CA. Capsaicin: A review of its pharmacology and clinical applications. Current Anaesthesia \& Critical Care 19 (2008) 338-343. doi:10.1016/j.cacc.2008.07.003

Bhalerao SA, Verma DR, Gavankar RV, Teli NC, Rane YY, Didwana VS and Trikannad A. 2013. Phytochemistry, Pharmacological Profile and Therapeutic Uses of Piper Betle Linn.- An Overview. Research and Reviews: Journal of Pharmacognosy and Phytochemistry. 1(2): 10-19

Guzman JD. Natural cinnamic acids, synthetic derivatives and hybrids with antimicrobial activity. Molecules. 2014;19(12):19292-19349. Published 2014 Nov 25. doi:10.3390/molecules191219292

Al-Samydai A ,Jaber N. (2018). Pharmacological aspects of curcumin: review article. International Journal of Pharmacognosy (IJP). 5(6).313-326. doi: 10.13040/IJPSR.0975-8232.

Nejad S M, Özgüneş H, Başaran N. (2017). Pharmacological and Toxicological Properties of Eugenol. The Turkish Journal of Pharmaceutical Sciences. 14(2): 201206. 10.4274/tjps.62207.

Amalraj A, Gopi S. 2016. Medicinal properties of Terminalia arjuna (Roxb.) Wight \& Arn.: A review. J Tradit Complement Med. 2016; 7(1):65-78. . doi:10.1016/j.jtcme.2016.02.003

Patel D. K., Patel K., Gadewar M., \& Tahilyani V. (2012). Pharmacological and bioanalytical aspects of galangin-a concise report. Asian Pacific Journal of Tropical Biomedicine, 2(1), S449-S455. doi:10.1016/s2221-1691(12)60205-6

Abedi F, Razavi B M, Hosseinzadeh H. (2019). A review on gentisic acid as a plant derived phenolic acid and metabolite of aspirin: Comprehensive pharmacology, toxicology, and some pharmaceutical aspects. Phytotherapy Research. doi:10.1002/ptr.6573

Prabu GR, Gnanamani A, Sadulla S. Guaijaverin-a plant flavonoid as potential antiplaque agent against Streptococcus mutans. Journal of Applied Microbiology. 2006 Aug;101(2):487-95. 
Imran M., Salehi B., Sharifi-Rad J., Aslam Gondal, T., Saeed, F., Imran, A. et al. (2019).

Kaempferol: A Key Emphasis to Its Anticancer Potential. Molecules, 24(12), 2277. doi:10.3390/molecules24122277

Lopez-Lazaro, M. (2009). Distribution and Biological Activities of the Flavonoid Luteolin. Mini-Reviews in Medicinal Chemistry, 9(1), 31-59. doi:10.2174/138955709787001712

Ohnishi R, Ito H, Iguchi A, Shinomiya K, Kamei C, Hatano T, Yoshida T. Effects of chlorogenic acid and its metabolites on spontaneous locomotor activity in mice. Bioscience, biotechnology, and biochemistry. 2006 Oct 23;70(10):2560-3.

Mgbeahuruike EE, Yrjönen T, Vuorela H \& Holm Y. (2017). Bioactive compounds from medicinal plants: Focus on Piper species. South African Journal of Botany. 112. 5469. 10.1016/j.sajb.2017.05.007.

Maalik A, Khan FA, Mumtaz A, Mehmood A, Azhar S, Atif M, Karim S, Altaf Y, Tari I . Pharmacological Applications of Quercetin and its Derivatives: A Short Review. Tropical Journal of Pharmaceutical Research. 2014; 13 (9): 1561-1566. DOI: 10.4314/tjpr.v13i9.26

Kumar V and Van Staden J. 2016. A Review of Swertia chirayita (Gentianaceae) as a Traditional Medicinal Plant. Front Pharmacol. 6:308. Published Jan 12. doi:10.3389/fphar.2015.00308

Singh RL, Singh P, Agarwal A. 2012. Chemical constituents and bio-pharmacological activities of Swertia chirata: A review. NPAIJ, 8(6), 238-247]

Ahmad A, Mishra RK, Vyawahare A, Kumar A, Rehman MU, Qamar W, Khan AQ, Khan R. 2019. Thymoquinone (2-Isopropyl-5-methyl-1, 4-benzoquinone) as a chemopreventive/anticancer agent: Chemistry and biological effects, Saudi Pharmaceutical Journal, Volume 27(8),1113-1126. https://doi.org/10.1016/j.jsps.2019.09.008.

Barrales-Cureño H J. Pharmacological applications and in vitro biotechnological production of anticancer alkaloids of Catharanthus roseus. Biotecnología Aplicada 2015;32:1101-10 
He, M., Min, J.-W., Kong, W.-L., He, X.-H., Li, J.-X., \& Peng, B.-W. (2016). A review on the pharmacological effects of vitexin and isovitexin. Fitoterapia, 115, 74-85. doi:10.1016/j.fitote.2016.09.011

Patel K, Singh RB, Patel DK. Pharmacological and analytical aspects of withaferin A: A concise report of current scientific literature. Asian Pacific Journal of Reproduction. 2013 Sep 1;2(3):238-43.

Johji Y, Michihiko M, Rong HQ, Hisashi M, Hajime F. The anti-ulcer effect in rats of ginger constituents. Journal of Ethnopharmacology. 1988 Jul 1;23(2-3):299-304.

Karimi A, Majlesi M, Rafieian-Kopaei M.Herbal versus synthetic drugs; beliefs and facts. J Nephropharmacol 2015; 4(1): 27-30.

Rose PW, Prlić A, Altunkaya A, Bi C, Bradley AR, Christie CH, et al. The RCSB protein data bank: Integrative view of protein, gene and 3D structural information. Nucleic Acids Res 2017;45:D271-81.

O'Boyle NM, Banck M, James CA, Morley C, Vandermeersch T, Hutchison GR. Open Babel: An open chemical toolbox. Journal of cheminformatics. 2011 Dec;3(1):33.

Kim S, Thiessen PA, Bolton EE, Chen J, Fu G, Gindulyte A, Han L, He J, He S, Shoemaker BA, Wang J. PubChem substance and compound databases. Nucleic acids research. 2016 Jan 4;44(D1):D1202-13.

Meng XY, Zhang HX, Mezei M, Cui M. Molecular docking: a powerful approach for structure-based drug discovery. Current computer-aided drug design. 2011 Jun $1 ; 7(2): 146-57$.

Kitchen DB, Decornez H, Furr JR, Bajorath J. Docking and scoring in virtual screening for drug discovery: methods and applications. Nature reviews Drug discovery. 2004 Nov;3(11):935-49.

Schneidman-Duhovny D, Inbar Y, Nussinov R, Wolfson HJ. PatchDock and SymmDock: servers for rigid and symmetric docking. Nucleic acids research. $2005 \mathrm{Jul}$ 1;33(suppl_2):W363-7. 
Zhang L, Lin D, Sun X, Curth U, Drosten C, Sauerhering L, Becker S, Rox K, Hilgenfeld R. Crystal structure of SARS-CoV-2 main protease provides a basis for design of improved $\alpha$-ketoamide inhibitors. Science. 2020 Mar 20.

Mashiach E, Schneidman-Duhovny D, Andrusier N, Nussinov R, Wolfson HJ. FireDock: a web server for fast interaction refinement in molecular docking. Nucleic acids research. 2008 Apr 19;36(suppl_2):W229-32.

Wang Q, He J, Wu D, Wang J, Yan J, Li H. Interaction of $\alpha$-cyperone with human serum albumin: Determination of the binding site by using Discovery Studio and via spectroscopic methods. Journal of Luminescence. 2015 Aug 1;164:81-5.

DeLano WL. Pymol: An open-source molecular graphics tool. CCP4 Newsletter on protein crystallography. 2002 Mar;40(1):82-92.

S.K. Balani; V.S.Devishree; G.T. Miwa; L.S. Gan; J.T. Wu; F.W. Lee (2005). "Strategy of utilizing in vitro and in vivo ADME tools for lead optimization and drug candidate selection". Curr Top Med Chem. 5 (11): 1033-8.

DainaA, O. Michielin, V. Zoete, SwissADME: A free web tool to evaluate pharmacokinetics, drug-likeness and medicinal chemistry friendliness of small molecules, Sci. Rep. 7 (2017) 42717.

Daina A., Zoete V., A BOILED-Egg to Predict Gastrointestinal Absorption and Brain Penetration of Small Molecules, ChemMedChem. 11 (2016) 1117-1121.

Wilder-Smith A, Chiew CJ, Lee VJ. Can we contain the COVID-19 outbreak with the same measures as for SARS?. The Lancet Infectious Diseases. 2020 Mar 5.

Lake MA. What we know so far: COVID-19 current clinical knowledge and research. Clinical Medicine. 2020 Mar;20(2):124.

Yuen KS, Ye ZW, Fung SY, Chan CP, Jin DY. SARS-CoV-2 and COVID-19: The most important research questions. Cell \& Bioscience. 2020 Dec;10(1):1-5.

Prompetchara E, Ketloy C, Palaga T. Immune responses in COVID-19 and potential vaccines: Lessons learned from SARS and MERS epidemic. Asian Pac J Allergy Immunol. 2020 Feb 27;38:1-9. 
Fang Y, Zhang H, Xie J, et al. Sensitivity of Chest CT for COVID-19: Comparison to RT-PCR. Radiology. 2020:200432

Dong, L., S. Hu, J. Gao, Discovering drugs to treat coronavirus disease 2019 (COVID19),

Drug Discov. Ther. 14 (2020) 58-60. https://doi.org/10.5582/ddt.2020.01012.

Zhou, D., S.-M. Dai, Q. Tong, COVID-19: a recommendation to examine the effect of hydroxychloroquine in preventing infection and progression., J. Antimicrob. Chemother. dkaa114 (2020).

Chang MW, Ayeni C, Breuer S, Torbett BE. Virtual screening for HIV protease inhibitors: a comparison of AutoDock 4 and Vina. PloS one. 2010;5(8).

Chan, J. F., Kok, K. H., Zhu, Z., Chu, H., To, K. K., Yuan, S., Yuen, K. Y. (2020). Genomic characterization of the 2019 novel human-pathogenic coronavirus isolated from a patient with atypical pneumonia after visiting Wuhan. Emerging microbes \& infections, 9(1), 221-236. https://doi.org/10.1080/22221751.2020.1719902

Hasan M, Ghosh PP, Azim KF, Mukta S, Abir RA, Nahar J, Khan MM. Reverse vaccinology approach to design a novel multi-epitope subunit vaccine against avian influenza A (H7N9) virus. Microbial pathogenesis. 2019 May 1;130:19-37.

Al-Tawfiq JA, Al-Homoud AH, Memish ZA. Remdesivir as a possible therapeutic option for the COVID-19. Travel Med Infect Dis. 2020 Mar 5;101615.

Colson P, Rolain JM, Lagier JC, Brouqui P, Raoult D. Chloroquine and hydroxychloroquine as available weapons to fight COVID-19. Int J Antimicrob Agents. 2020 Mar 4;105932.

Parvez et al., 2020. Prediction of potential inhibitors for RNA-dependent RNA polymerase of SARSCoV-2 using comprehensive drug repurposing and molecular docking approach. BioRxIV. https://www.researchgate.net/publication/340662572

Hasan et al., 2020. Main Protease Inhibitors and Drug Surface Hotspot for the Treatment of COVID-19: Drug Repurposing and Molecular Docking Approach BioRxIV. https://www.researchgate.net/publication/340719193 
Hilgenfeld, R. From SARS to MERS: Crystallographic Studies on Coronaviral Proteases Enable Antiviral Drug Design. FEBS J. 2014, 281, 4085-4096.

Moore, J. P., and R. W. Doms. The entry of entry inhibitors: a fusion of science and medicine. Proc. Natl. Acad. Sci. USA. 2003, 100, 10598-10602

Banerjee P., Eckert O.A., Schrey A.K., Preissner R.: ProTox-II: a webserver for the prediction of toxicity of chemicals. Nucleic Acids Res (Web server issue 2018); NAR

Sander, T 2001. OSIRIS property explorer. Organic Chemistry Portal. https://www.organicchemistry.org/prog/peo/ (accessed on April 21, 2020).

Daina A, Michielin O, Zoete V. SwissTargetPrediction: updated data and new features for efficient prediction of protein targets of small molecules. Nucleic acids research. 2019 Jul 2;47(W1):W357-64.

Zoete, V., Daina, A., Bovigny, C., \& Michielin, O. SwissSimilarity: A Web Tool for Low to Ultra High Throughput Ligand-Based Virtual Screening., J. Chem. Inf. Model., 2016, 56(8), 1399-1404.

Guan, L., Yang, H., Cai, Y., Sun, L., Di, P., Li, W., Liu, G. and Tang, Y., 2019. ADMET-score-a comprehensive scoring function for evaluation of chemical druglikeness. Medchemcomm, 10(1), pp.148-157.

Habbu, P.V., Mahadevan, K.M., Shastry, R.A. and Manjunatha, H., 2009. Antimicrobial activity of flavanoid sulphates and other fractions of Argyreia speciosa (Burm. f) Boj.

Indwiani Astuti, Y., Severe Acute Respiratory Syndrome Coronavirus 2 (SARS-CoV-2): An overview of viral structure and host response. Diabetes \& Metabolic Syndrome.

Joseph, J., Bhaskaran, R., Kaliraj, M., Muthuswamy, M. and Suresh, A., 2017. Molecular Docking of Phytoligands to the viral protein receptor P. monodon Rab7. Bioinformation, 13(4), p.116.

Wishart, D.S., 2007. Improving early drug discovery through ADME modelling. Drugs in R \& D, 8(6), pp.349-362. 
Prabu, G.R.; Gnanamani, A.; Sadulla, S. Guaijaverin-A plant flavonoid as potential antiplaque agent against Streptococcus mutans. J. Appl. Microbiol. 2006, 101, 487495. doi:10.1111/j.1365-2672.2006.02912.x

Bian D, Zhang J, Wu X, Dou Y, Yang Y, Tan Q, Xia Y, Gong Z, Dai Y. Asiatic Acid Isolated From Centella Asiatica Inhibits TGF- $\beta 1$-induced Collagen Expression in Human Keloid Fibroblasts via PPAR- $\gamma$ Activation. International Journal of Biological Sciences. 2013; 9(10):1032-1042. doi: 10.7150/ijbs.7273

Cai Z, Zhang G,Tang B, Liu Y, Fu X, Zhang X. Promising Anti-influenza Properties of Active Constituent of Withania somnifera Ayurvedic Herb in Targeting Neuraminidase of H1N1 Influenza: Computational Study. Cell Biochem Biophys (2015) 72:727-739. DOI 10.1007/s12013-015-0524-9

Grover A, Agrawal V,Shandilya A, Bisaria VS, Sundar D. Non-nucleosidic inhibition of Herpes simplex virus DNA polymerase: mechanistic insights into the anti-herpetic mode of action of herbal drug withaferin A. BMC Bioinformatics. 2011, 12(Suppl 13):S22

Kim S M, Kang K, Jho E H, Jung Y-J, Nho C W, Um B-H, \& Pan C-H. (2011). Hepatoprotective Effect of Flavonoid Glycosides from Lespedeza cuneata against Oxidative Stress Induced by tert-Butyl Hyperoxide. Phytotherapy Research, 25(7), 1011-1017. doi:10.1002/ptr.3387

Krishnamurthy RG, Senut M,Zemke D, Min J, Frenkel MB, Greenberg EJ, Yu S et al.Asiatic Acid, a Pentacyclic Triterpene From Centella asiatica, Is Neuroprotective in a Mouse Model of Focal Cerebral Ischemia. Journal of Neuroscience Research 87:2541-2550 (2009). DOI: 10.1002/jnr.22071

Lee JS, Lee AY, Quilantang NG, Geraldino PJL, Cho EJ, Lee S.. Anti-oxidant activity of avicularin and isovitexin from Lespedeza cuneata. J Appl Biol Chem (2019) 62(2), 143-147 https://doi.org/10.3839/jabc.2019.020

Shen, Z., Xu, Y., Jiang, X., Wang, Z., Guo, Y., Pan, W., \& Hou, J. (2019). Avicularin Relieves Depressive-Like Behaviors Induced by Chronic Unpredictable Mild Stress in Mice. Medical science monitor: international medical journal of experimental and clinical research, 25, 2777-2784. https://doi.org/10.12659/MSM.912401 
Shi T, Wilhelm E, Bell B and Dumais N. Nf-kb-Dependent Inhibition of HIV-1 Transcription by Withaferin A. HIV Curr Res 2017, 2:1. DOI: 10.4172/25720805.1000119

Tiwari S, Atluri VSR, Yndart Arias A, et al. Withaferin A Suppresses Beta Amyloid in APP Expressing Cells: Studies for Tat and Cocaine Associated Neurological Dysfunctions. Front Aging Neurosci. 2018;10:291. Published 2018 Sep 27. doi:10.3389/fnagi.2018.00291

Vaishnavi K, Saxena N, Shah N, et al. Differential activities of the two closely related withanolides, Withaferin A and Withanone: bioinformatics and experimental evidences. PLoS One. 2012;7(9):e44419. doi:10.1371/journal.pone.0044419

Vo VA,Lee JW, Chang JE, Kim JY, Kim NH, HJ Lee, Kim SS, Chun W and Kwon YS. Avicularin Inhibits Lipopolysaccharide-Induced Inflammatory Response by Suppressing ERK Phosphorylation in RAW 264.7 Macrophages. Biomol Ther 20(6), 532-537 (2012)

Wang W, Zheng H, Zheng M, Liu X, Yu J. Protective effect of avicularin on rheumatoid arthritis and its associated mechanisms. Exp Ther Med. 2018;16(6):5343-5349. doi:10.3892/etm.2018.6872

White PT, Subramanian C, Motiwala HF, Cohen MS. Natural Withanolides in the Treatment of Chronic Diseases. Adv Exp Med Biol. 2016;928:329-373. doi:10.1007/978-3-319-41334-1_14

Wen O, Xiaoai Z, Lei S, Xuexiang C, Shumin Y, Yong C. Hypoglycemic Activity of Avicularin and Guaijaverin in Guava Leaves[J]. FOOD SCIENCE, 2016, 37(7): 168174. Availablefrom: http://www.spkx.net.cn/EN/Y2016/V37/I7/168

World Health Organization (WHO), 2020. Available from: https://www.who.int/emergencies/diseases/novel-coronavirus-2019 (Accessed date: 3 May, 2020)

Barzilai, D., Plavnick, J., Hazani, A., Einath, R., Kleinhaus, N. and Kanter, Y., 1972. Use of hydrocortisone in the treatment of acute myocardial infarction: summary of a clinical trial in 446 patients. Chest, 61(5), pp.488-491. 
Jung, K., Wang, Q., Kim, Y., Scheuer, K., Zhang, Z., Shen, Q., Chang, K.O. and Saif, L.J., 2012. The effects of simvastatin or interferon- $\alpha$ on infectivity of human norovirus using a gnotobiotic pig model for the study of antivirals. PloS one, 7(7).

Ong, K.C. and Khoo, H.E., 1997. Biological effects of myricetin. General Pharmacology: The Vascular System, 29(2), pp.121-126.

Moldovan Z, Bunaciu AA, Al-Omar MA, Aboul-Enein HY. (2010) A spectrophotometric method for diosmin determination. The Open Chemical and Biomedical Methods Journal, 3, 123-127.

\section{Figure Legends}

Figure 1: Chemical structures of Asiatic acid (A), Guenjaverin (B), Avicularin (C) and Witheferin (D)

Figure 2: Molecular interaction of Asiatic acid with SARS-CoV-2 main protease (A), Nsp9 RNA binding protein (B) and spike ectodomain (C)

Figure 3: Molecular interaction of SARS-CoV-2 main protease with Avicularin (A), HR2 Domain with Guenjaverin (B) and spike receptor-binding domain with Guenjaverin (C)

Figure 4: ADME analysis of top four metabolites; A: Asiatic acid, B: Guenjaverin, C: Avicularin, and D: Witheferin

Figure 5: Toxicity patterns of top four drug candidates; A: Asiatic acid, B: Guenjaverin, C: Avicularin, and D: Witheferin

Figure 6: Prediction of drug targets for Asiatic acid (A), Guenjaverin (B), Avicularin (C) and Witheferin (D) 


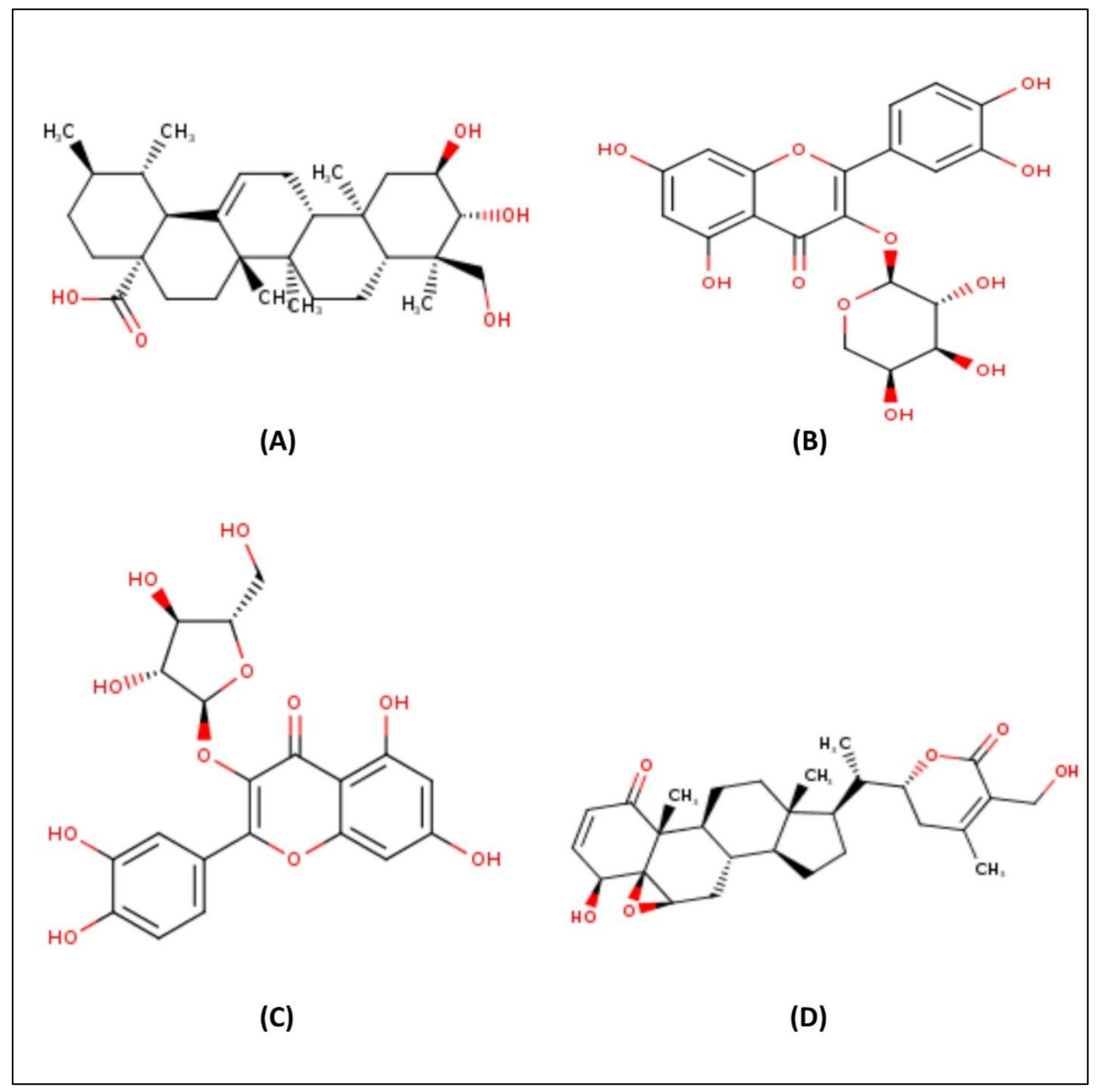

Figure 1: Chemical structures of Asiatic acid (A), Guenjaverin (B), Avicularin (C) and Witheferin (D) 
(A)
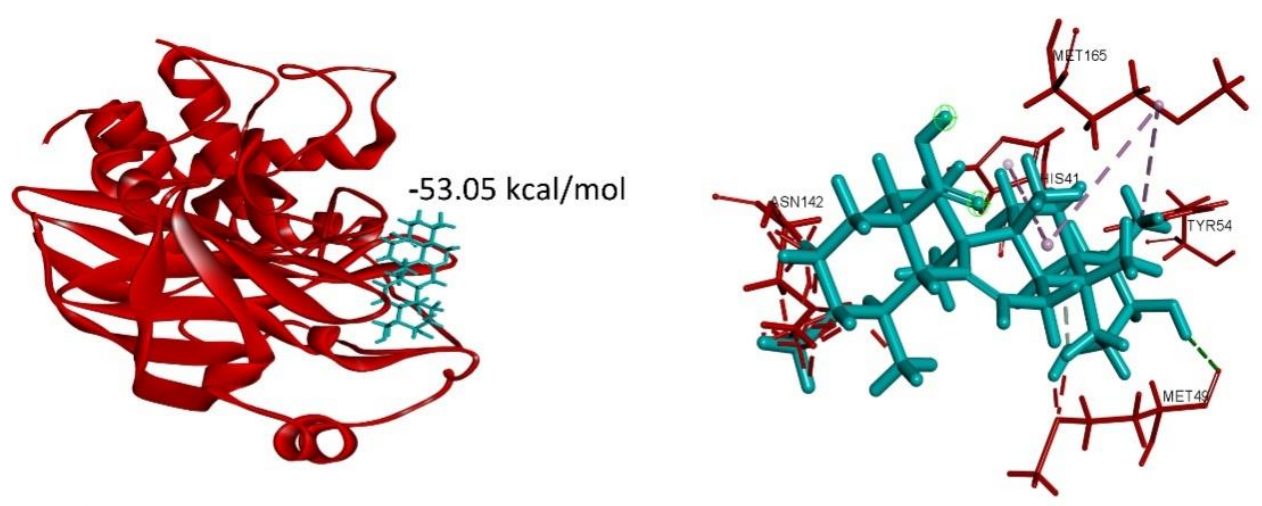

(B)
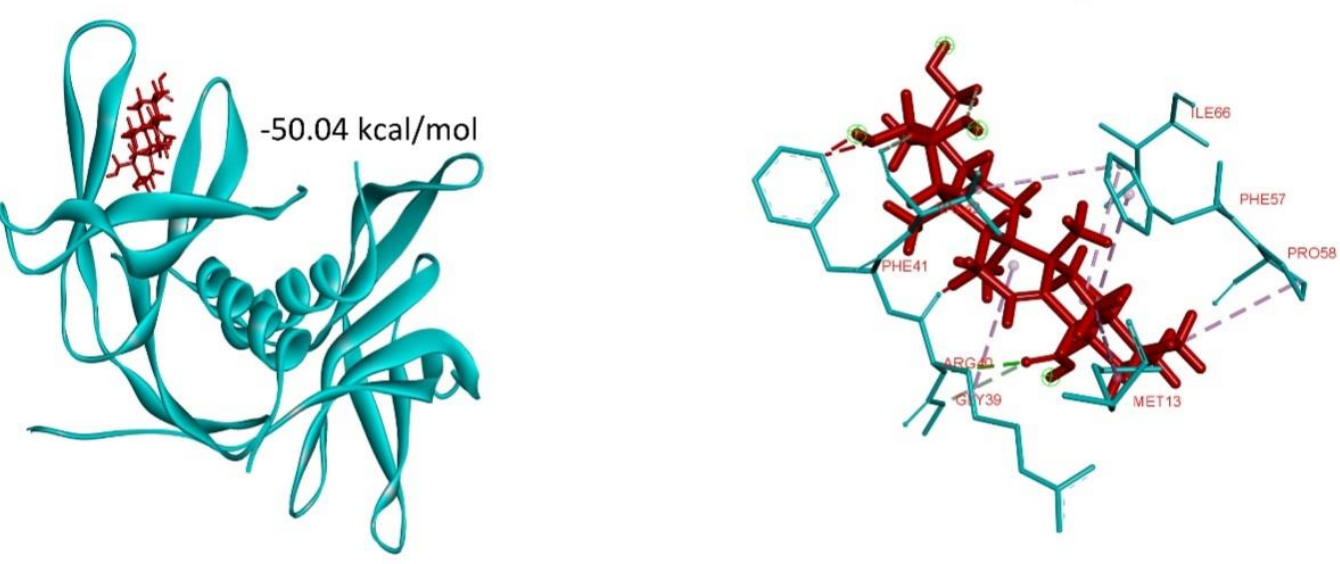

(C)
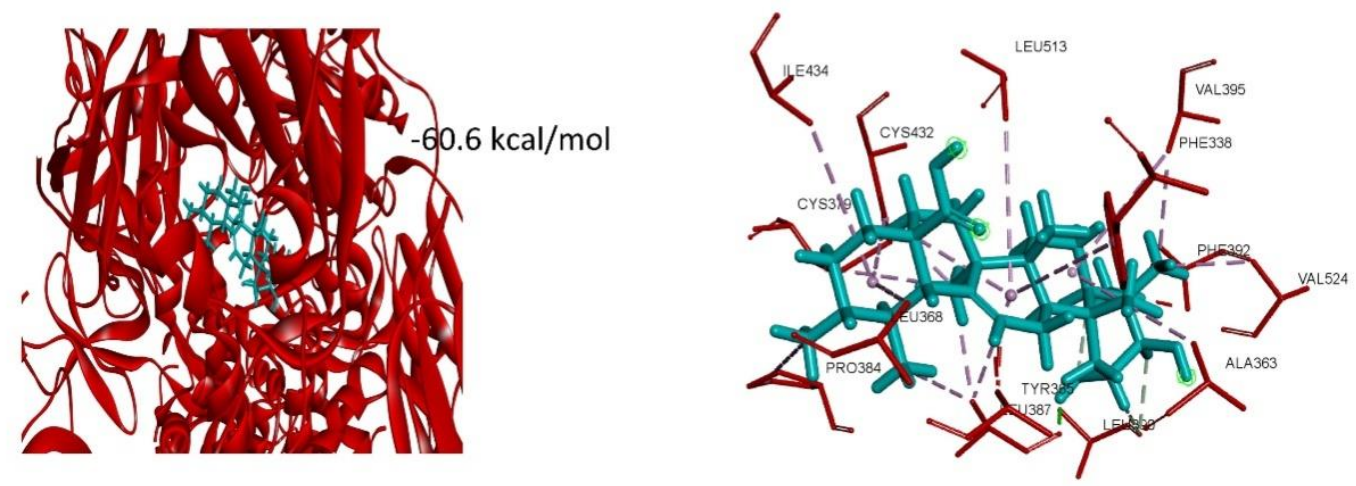

Figure 2: Molecular interaction of Asiatic acid with SARS-CoV-2 main protease (A), Nsp9 RNA binding protein (B) and spike ectodomain (C) 


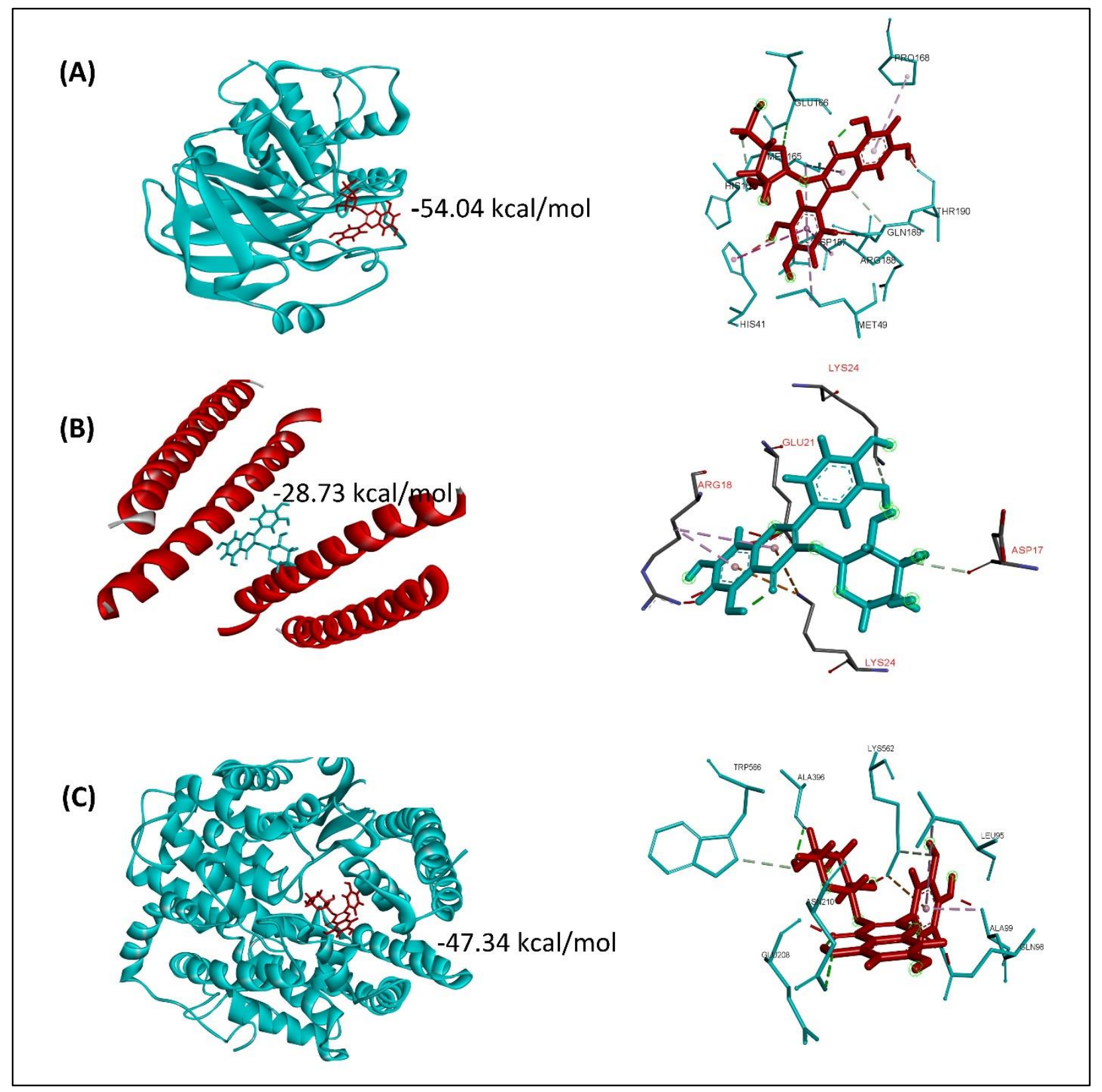

Figure 3: Molecular interaction of SARS-CoV-2 main protease with Avicularin (A), HR2

Domain with Guenjaverin (B) and spike receptor-binding domain with Guenjaverin (C) 


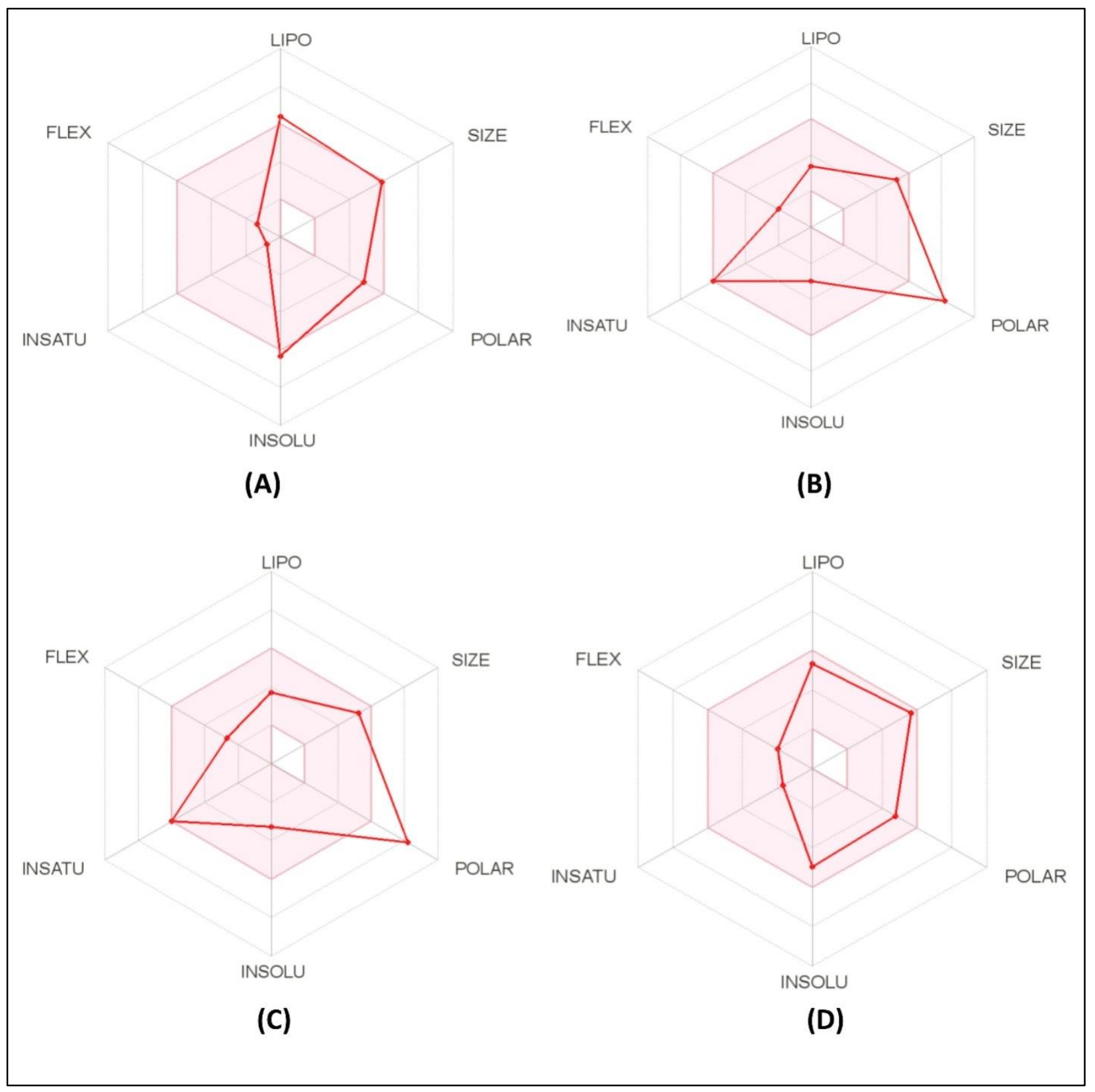

Figure 4: ADME analysis of top four metabolites; A: Asiatic acid, B: Guenjaverin, C:

Avicularin, and D: Witheferin 


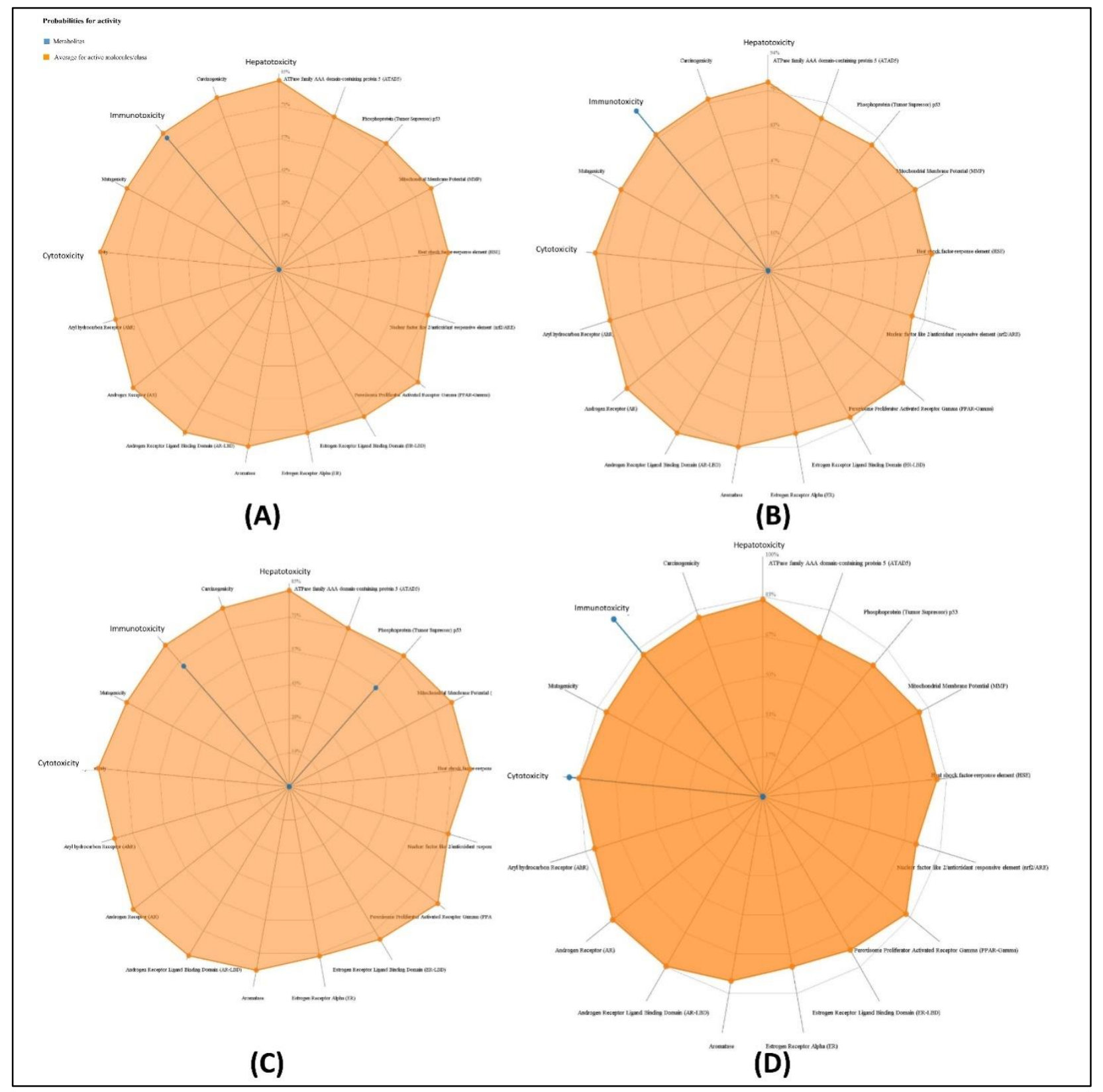

Figure 5: Toxicity patterns of top four drug candidates; A: Asiatic acid, B: Guenjaverin, C: Avicularin, and D: Witheferin 


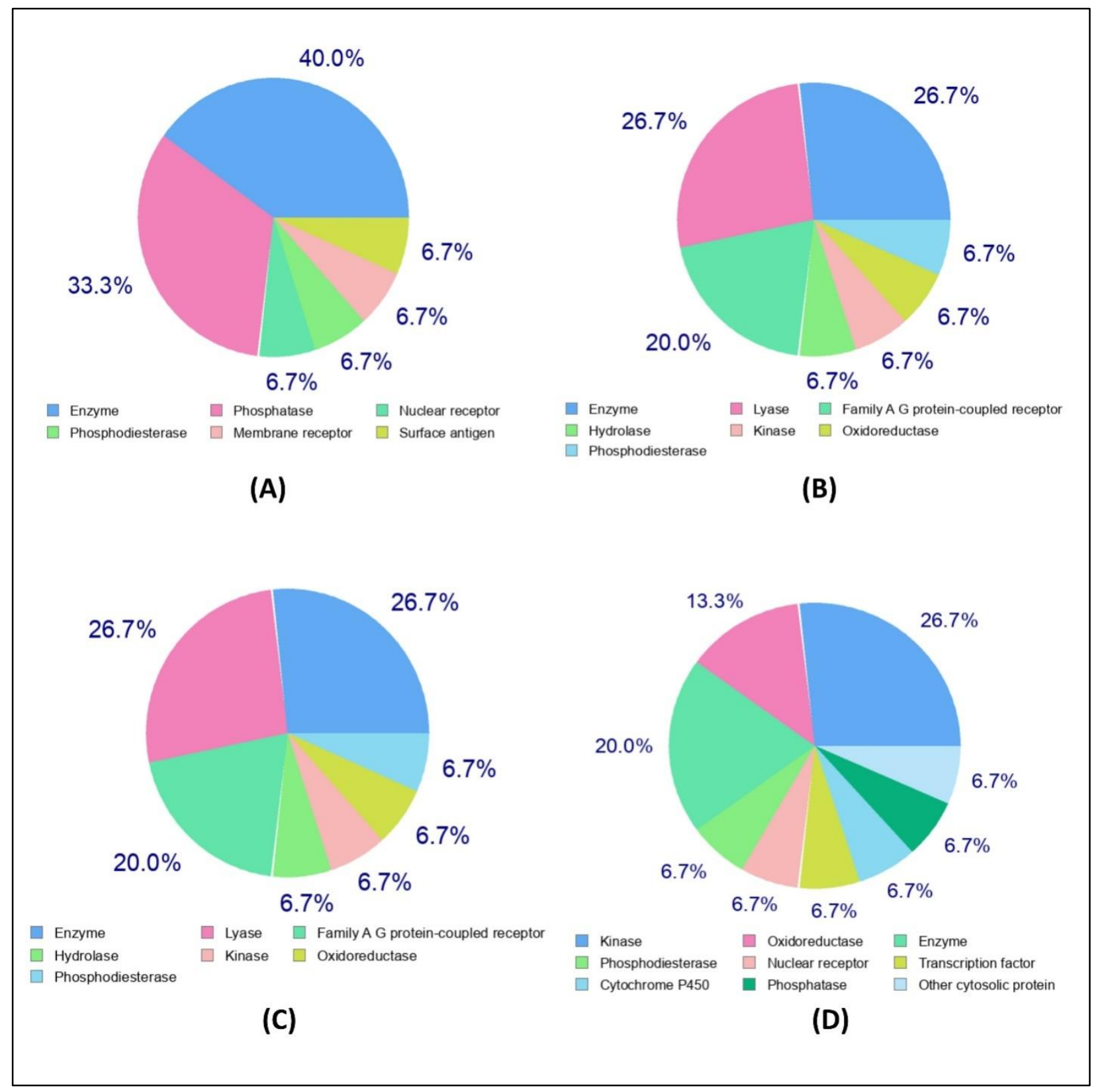

Figure 6: Prediction of drug targets for Asiatic acid (A), Guenjaverin (B), Avicularin (C) and Witheferin (D) 
Tables

Table 1: List of plant metabolites used in the study with respective source and activities

\begin{tabular}{|c|c|c|c|c|c|}
\hline Metabolites & $\begin{array}{l}\text { Pubchem } \\
\text { CID }\end{array}$ & Class & Source & Activities & References \\
\hline Alicin & 65036 & $\begin{array}{l}\text { S-containing } \\
\text { compound }\end{array}$ & $\begin{array}{l}\text { Allium } \\
\text { sativum }\end{array}$ & $\begin{array}{lr}\begin{array}{l}\text { Antimicrorial, } \\
\text { Antioxidant, } \\
\text { activity }\end{array} & \text { anti-cancer } \\
\end{array}$ & $\begin{array}{l}\text { El-Saber Batiha et } \\
\text { al., } 2020\end{array}$ \\
\hline Andrographolide & 5318517 & $\begin{array}{l}\text { Diterpenoid } \\
\text { labdane }\end{array}$ & $\begin{array}{l}\text { Andrographis } \\
\text { paniculata }\end{array}$ & $\begin{array}{l}\text { antioxidant, anti-inflammatory, } \\
\text { and anti-cancer }\end{array}$ & $\begin{array}{l}\text { Mussard et al., } \\
2019\end{array}$ \\
\hline Apigenin & 5280443 & Flavonoid & $\begin{array}{l}\text { Vegetable and } \\
\text { fruit }\end{array}$ & $\begin{array}{l}\text { Effective in } \\
\text { depression, diabetes \& \& } \\
\text { Alzheimer's disease, }\end{array}$ & Salehi et al., 2019 \\
\hline Asiatic acid & 119034 & $\begin{array}{l}\text { Aglycone type } \\
\text { pentacyclic } \\
\text { triterpenoids }\end{array}$ & $\begin{array}{l}\text { Centella } \\
\text { asiatica }\end{array}$ & $\begin{array}{l}\text { Antioxidant, cardioprotective, } \\
\text { anti-inflammatory, antitumor, } \\
\text { neuroprotective, antimicrobial }\end{array}$ & $\begin{array}{l}\text { Nagoor Meeran et } \\
\text { al., } 2018\end{array}$ \\
\hline Avicularin & 5490064 & $\begin{array}{l}\text { quercetin-3-a-L } \\
\text { arabinofuranoside } \\
\text { (flavonoid) }\end{array}$ & $\begin{array}{l}\text { Psidium } \\
\text { guyava, } \\
\text { Lespedeza } \\
\text { cuneata } \\
\end{array}$ & $\begin{array}{l}\text { anti-inflammatory, anti- } \\
\text { oxidant, hepatoprotective } \\
\text { activity }\end{array}$ & Wang et al., 2019 \\
\hline Capsaicin & 1548943 & Alkaloid & $\begin{array}{l}\text { Capsicum } \\
\text { genus }\end{array}$ & $\begin{array}{l}\text { Pruritis, pain relief, non- } \\
\text { steroidal anti-inflammatory } \\
\text { drug induced gastritis }\end{array}$ & $\begin{array}{l}\text { Hayman and } \\
\text { Kam, 2008 }\end{array}$ \\
\hline Chavibetol & 596375 & Phenylpropanoid & Piper betle & $\begin{array}{l}\text { immunomodulatory, radical } \\
\text { scavenging }\end{array}$ & $\begin{array}{l}\text { Bhalerao et al., } \\
2013\end{array}$ \\
\hline Cinnamic & 444539 & $\begin{array}{l}\text { Aromatic } \\
\text { carboxylic acids }\end{array}$ & $\begin{array}{l}\text { Cinnaтотит } \\
\text { species }\end{array}$ & $\begin{array}{l}\text { Antibacterial, antifungal, } \\
\text { antimalarial, antitubercular }\end{array}$ & Guzman, 2014 \\
\hline Curcumin & 969516 & $\begin{array}{l}\text { Polyphenolic } \\
\text { compound }\end{array}$ & $\begin{array}{l}\text { Curcuma } \\
\text { longa }\end{array}$ & $\begin{array}{l}\text { antibacterial, } \begin{array}{l}\text { anti- } \\
\text { inflammatory } \\
\text { antioxidant, anti-arthritis \& \& } \\
\text { anti-cancer activity }\end{array} \\
\end{array}$ & $\begin{array}{l}\text { Al-Samydai and } \\
\text { Jaber, } 2018\end{array}$ \\
\hline Eugenol & 3314 & Phenylpropanoid & $\begin{array}{l}\text { Ocimum } \\
\text { tenuiflorum, } \\
\text { Eugenia } \\
\text { caryophyllata }\end{array}$ & $\begin{array}{l}\text { antimicrobial, } \\
\text { inflammatory, analgesic anti- } \\
\text { antioxidant }\end{array}$ & Nejad et al., 2017 \\
\hline Flavonoidsarjunone & 14034821 & Flavonoids & $\begin{array}{l}\text { Terminalia } \\
\text { arjuna }\end{array}$ & $\begin{array}{l}\text { Arjunone and other } \\
\text { compounds have role in } \\
\text { antioxidant, antiatherogenic, } \\
\text { anti-inflammatory, anti- } \\
\text { carcinogenic activity }\end{array}$ & $\begin{array}{l}\text { Amalraj } \\
\text { Gopi, } 2016\end{array}$ \\
\hline Galangin & 5281616 & Flavonol & $\begin{array}{l}\text { Honey, } \\
\text { Alpinia } \\
\text { officinarum, } \\
\text { propolis } \\
\end{array}$ & $\begin{array}{lr}\text { Anti-cancer, } & \text { anti-mutagenic, } \\
\text { anti-oxidative, } & \text { radical } \\
\text { scavenging etc. } & \end{array}$ & Patel et al., 2012 \\
\hline Gentisic acid & 3469 & Phenolic acid & $\begin{array}{l}\text { Gentiana, } \\
\text { Citrus, } H . \\
\text { rosa-sinensis, } \\
\text { O. } \\
\text { europaea,S. } \\
\text { indicum }\end{array}$ & $\begin{array}{l}\text { Antioxidant, neuroprotective, } \\
\text { antiinflammatory, } \\
\text { hepatoprotective, antimicrobial } \\
\text { activities }\end{array}$ & Abedi et al., 2019 \\
\hline Guajaverin & 5481224 & Flavonoid & $\begin{array}{l}\text { Psidium } \\
\text { guyava }\end{array}$ & Anti-plaque activity & Prabu et al., 2006 \\
\hline
\end{tabular}




\begin{tabular}{|c|c|c|c|c|c|}
\hline Kaempferol & 5280863 & $\begin{array}{l}\text { Flavonoid } \\
\text { aglycone }\end{array}$ & $\begin{array}{l}\text { Vegetable and } \\
\text { fruit }\end{array}$ & $\begin{array}{l}\text { Anti-inflammatory, antioxidant, } \\
\text { antimicrobial, antitumor, } \\
\text { cardioprotective, } \\
\text { and antidiabetic activities }\end{array}$ & Imran et al., 2019 \\
\hline Luteolin & 5280445 & Flavonoid & $\begin{array}{l}\text { Carrots, } \\
\text { celery } \\
\text { peppers, olive } \\
\text { peppermint } \\
\end{array}$ & $\begin{array}{l}\text { Anticancer, antioxidant, } \\
\text { antimicrobial, anti- } \\
\text { inflammatory, and activities }\end{array}$ & $\begin{array}{l}\text { Lopez-Lazaro, } \\
2009\end{array}$ \\
\hline m-Coumaric acid & 637541 & Phenolic acid & $\begin{array}{l}\text { Solanum } \\
\text { nigrum }\end{array}$ & $\begin{array}{l}\text { Role in pharmacological } \\
\text { activities }\end{array}$ & $\begin{array}{l}\text { Ohnishi et al., } \\
2006\end{array}$ \\
\hline Piperic acid & 5370536 & Alkaloid & Piper nigrum & No known function & $\begin{array}{l}\text { Mgbeahuruike et } \\
\text { al., } 2017\end{array}$ \\
\hline Piperine & 638024 & Alkaloid & Piper spp. & $\begin{array}{l}\text { Anticancer, antimicrobial, } \\
\text { antimalarial }\end{array}$ & $\begin{array}{l}\text { Mgbeahuruike et } \\
\text { al., } 2017\end{array}$ \\
\hline Quercetine & 5280343 & Flavonoid & $\begin{array}{l}\text { Diverse plant } \\
\text { species }\end{array}$ & $\begin{array}{l}\text { Antioxidant, cardiovascular, } \\
\text { antiviral, anti-inflammatory, } \\
\text { anticancer, antimicrobial }\end{array}$ & $\begin{array}{l}\text { Maalik et al., } \\
2014\end{array}$ \\
\hline Swertiamarin & 442435 & $\begin{array}{l}\text { Secoiridoid } \\
\text { glycoside }\end{array}$ & $\begin{array}{l}\text { Swertia } \\
\text { chirata }\end{array}$ & $\begin{array}{l}\text { Anti-arthritic, anti-diabetic } \\
\text { Cardio-protective, Anticancer, } \\
\text { Anti-hepatitis, Antibacterial, } \\
\text { anti-atherosclerotic }\end{array}$ & $\begin{array}{l}\text { Kumar and Van } \\
\text { Staden, } 2016\end{array}$ \\
\hline Swertinin & 5491517 & $\begin{array}{l}\text { Secoiridoid } \\
\text { glycoside }\end{array}$ & $\begin{array}{l}\text { Swertia } \\
\text { chirata }\end{array}$ & $\begin{array}{l}\text { Role in pharmacological } \\
\text { activities }\end{array}$ & Singh et al., 2012 \\
\hline Thymoquinone & 10281 & Monoterpene & Nigella sativa & $\begin{array}{l}\text { Anti-oxidant and anti- } \\
\text { inflammatory properties, Anti- } \\
\text { microbial, Anti-arthritic, anti- } \\
\text { cancer efficacy }\end{array}$ & $\begin{array}{l}\text { Ahmad et al., } \\
\text { 2019; }\end{array}$ \\
\hline Vincamine & 15376 & Alkaloid & $\begin{array}{l}\text { Catharanthus } \\
\text { roseus, Vinca } \\
\text { minor }\end{array}$ & $\begin{array}{l}\text { Cerebral disorders, antiulcer } \\
\text { activity, } \\
\text { insufficiencies }\end{array}$ & $\begin{array}{l}\text { Barrales-Cureño, } \\
2015\end{array}$ \\
\hline Vitexin & 5280441 & $\begin{array}{l}\text { Apigenin flavone } \\
\text { glucoside }\end{array}$ & $\begin{array}{l}\text { Crataegus } \\
\text { species }\end{array}$ & $\begin{array}{l}\text { Anti-inflammatory effects, } \\
\text { anti-oxidant effects, anti- } \\
\text { carcinogenic effects, anti-viral } \\
\text { effects }\end{array}$ & He et al., 2016 \\
\hline Withaferin & 265237 & Steroidal lactone & $\begin{array}{l}\text { Withania } \\
\text { somnifera }\end{array}$ & $\begin{array}{l}\text { Anti-cancer, adaptogenic, anti- } \\
\text { stress, immunomodulatory, } \\
\text { anti-inflammatory, anti-tumor, } \\
\text { cardioprotective, and } \\
\text { neuroprotective activities. }\end{array}$ & Patel et al., 2013 \\
\hline Zingiberene & 92776 & Isoprenoids & $\begin{array}{l}\text { Zingiber } \\
\text { Officinale }\end{array}$ & $\begin{array}{l}\text { Anti-ulcer, } \\
\text { cytoxic effect }\end{array}$ & Johji et al., 1988 \\
\hline
\end{tabular}

Table 2: Analysis ofglobal binding energy of top 4 screened metabolites (ligands) 


\begin{tabular}{|c|c|c|c|c|c|}
\hline Macromolecules & Ligands & Global Energy & ACE & Score & Area \\
\hline \multirow{5}{*}{ 6W63 } & $\alpha$-ketoamide(Control) & -56.92 & -16.84 & 4560 & 526.40 \\
\hline & Asiatic acid & -53.05 & -15.26 & 4916 & 577.10 \\
\hline & Avicularin & -48.62 & -18.50 & 4694 & 532.10 \\
\hline & Guajaverin & -48.48 & -15.12 & 4450 & 497.50 \\
\hline & Withaferin & -48.46 & -14.08 & 4984 & 597.40 \\
\hline \multirow{5}{*}{$6 \mathrm{~W} 4 \mathrm{~B}$} & $\alpha$-ketoamide (Control) & -48.60 & -16.39 & 4458 & 504.60 \\
\hline & Asiatic acid & -50.04 & -16.37 & 4998 & 564.20 \\
\hline & Withaferin & -47.95 & -13.30 & 4896 & 570.40 \\
\hline & Guajaverin & -42.72 & -10.63 & 4548 & 641.40 \\
\hline & Avicularin & -39.83 & -235.80 & 4556 & 514.50 \\
\hline \multirow{5}{*}{$6 \mathrm{VYB}$} & $\alpha$-ketoamide (Control) & -63.94 & -17.32 & 5728 & 705.10 \\
\hline & Asiatic acid & -60.68 & -22.33 & 6276 & 771.50 \\
\hline & Withaferin & -60.19 & -20.49 & 5760 & 793.10 \\
\hline & Guajaverin & -55.24 & -17.51 & 5208 & 659.20 \\
\hline & Avicularin & -52.93 & -17.15 & 5474 & 683.30 \\
\hline \multirow{5}{*}{$6 \mathrm{LVN}$} & $\alpha$-ketoamide (Control) & -25.52 & -2.71 & 4318 & 564.20 \\
\hline & Guajaverin & -28.73 & -2.13 & 3696 & 443.50 \\
\hline & Withaferin & -28.11 & -1.24 & 4376 & 507.70 \\
\hline & Asiatic acid & -27.58 & -1.12 & 4366 & 500.30 \\
\hline & Avicularin & -26.48 & -1.22 & 3986 & 465.10 \\
\hline \multirow{5}{*}{$6 \mathrm{M} 0 \mathrm{~J}$} & $\alpha$-ketoamide (Control) & -60.50 & -9.34 & 5374 & 655.40 \\
\hline & Guajaverin & -47.34 & -11.22 & 4554 & 575.60 \\
\hline & Withaferin & -46.84 & -11.13 & 5598 & 640.50 \\
\hline & Asiatic acid & -45.69 & -13.09 & 5978 & 691.70 \\
\hline & Avicularin & -43.13 & -11.09 & 5232 & 604.20 \\
\hline \multirow{5}{*}{ 6LU7 } & $\alpha$-ketoamide (Control) & -56.13 & -15.07 & 4578 & 492.00 \\
\hline & Avicularin & -54.04 & -14.77 & 4584 & 520.60 \\
\hline & Guajaverin & -51.69 & -12.92 & 4182 & 515.50 \\
\hline & Withaferin & -47.08 & -14.06 & 4708 & 560.60 \\
\hline & Asiatic acid & -43.52 & -13.90 & 5050 & 562.20 \\
\hline
\end{tabular}

Table 3: Drug profile and ADME analysis of top four metabolites 


\begin{tabular}{|c|c|c|c|c|c|}
\hline \multirow{2}{*}{\multicolumn{2}{|c|}{ Parameter }} & \multicolumn{4}{|c|}{ Top Main Protease Protein Inhibitors of SARS-CoV-2 } \\
\hline & & \multirow{2}{*}{$\begin{array}{l}\text { Asiatic acid } \\
\mathrm{C} 30 \mathrm{H} 48 \mathrm{O} 5\end{array}$} & \multirow{2}{*}{$\begin{array}{c}\text { Guajaverin } \\
\mathrm{C} 20 \mathrm{H} 18 \mathrm{O} 11\end{array}$} & \multirow{2}{*}{$\begin{array}{l}\text { Avicularin } \\
\mathrm{C} 20 \mathrm{H} 18 \mathrm{O} 11\end{array}$} & \multirow{2}{*}{$\begin{array}{l}\text { Witheferin } \\
\text { C28H38O6 }\end{array}$} \\
\hline \multirow{6}{*}{$\begin{array}{l}\text { Physicochemical } \\
\text { parameters }\end{array}$} & Formula & & & & \\
\hline & Molecular weight & $488.70 \mathrm{~g} / \mathrm{mol}$ & $434.35 \mathrm{~g} / \mathrm{mol}$ & $434.35 \mathrm{~g} / \mathrm{mol}$ & $470.60 \mathrm{~g} / \mathrm{mol}$ \\
\hline & No. H-bond acceptors & 5 & 11 & 11 & 6 \\
\hline & No. H-bond donors & 4 & 7 & 7 & 2 \\
\hline & Molar Refractivity & 139.24 & 104.19 & 104.19 & 127.49 \\
\hline & TPSA & $97.99 \AA^{2}$ & $190.28 \AA^{2}$ & $190.28 \AA^{2}$ & $96.36 \AA^{2}$ \\
\hline \multirow{6}{*}{ Lipophilicity } & $\log P_{\mathrm{o} / \mathrm{w}}(\mathrm{iLOGP})$ & 2.95 & 1.77 & 1.86 & 3.24 \\
\hline & $\log P_{\mathrm{o} / \mathrm{w}}(\mathrm{XLOGP3})$ & 5.70 & 0.43 & 0.98 & 3.83 \\
\hline & $\log P_{\mathrm{o} / \mathrm{w}}($ WLOGP $)$ & 5.03 & 0.10 & 0.10 & 3.35 \\
\hline & $\log P_{\mathrm{o} / \mathrm{w}}($ MLOGP $)$ & 4.14 & -2.06 & -2.06 & 2.75 \\
\hline & $\log P_{\mathrm{o} / \mathrm{w}}($ SILICOS-IT) & 3.96 & -0.10 & 0.06 & 3.93 \\
\hline & Consensus $\log P_{\mathrm{o} / \mathrm{w}}$ & 4.36 & 0.03 & 0.19 & 3.42 \\
\hline \multirow{9}{*}{ Pharmacokinetics } & GI absorption & High & Low & Low & High \\
\hline & BBB permeant & No & No & No & No \\
\hline & P-gp substrate & Yes & No & No & Yes \\
\hline & CYP1A2 inhibitor & No & No & No & No \\
\hline & CYP2C19 inhibitor & No & No & No & No \\
\hline & CYP2C9 inhibitor & No & No & No & No \\
\hline & CYP2D6 inhibitor & No & No & No & No \\
\hline & CYP3A4 inhibitor & No & No & No & No \\
\hline & $\begin{array}{l}\log K_{\mathrm{p}}(\text { skin } \\
\text { permeation })\end{array}$ & $-5.23 \mathrm{~cm} / \mathrm{s}$ & $-8.64 \mathrm{~cm} / \mathrm{s}$ & $-8.25 \mathrm{~cm} / \mathrm{s}$ & $-6.45 \mathrm{~cm} / \mathrm{s}$ \\
\hline \multirow{6}{*}{ Water Solubility } & $\log S(\mathrm{ESOL})$ & -6.33 & -2.99 & -3.27 & -4.97 \\
\hline & Solubility & $\begin{array}{c}2.29 \mathrm{e}-4 \mathrm{mg} / \mathrm{ml} \\
4.69 \mathrm{e}-7 \mathrm{~mol} / \mathrm{l}\end{array}$ & $\begin{array}{c}4.47 \mathrm{e}-01 \mathrm{mg} / \mathrm{ml} ; \\
1.03 \mathrm{e}-03 \mathrm{~mol} / \mathrm{l}\end{array}$ & $\begin{array}{c}2.34 \mathrm{e}-01 \mathrm{mg} / \mathrm{ml} \\
5.39 \mathrm{e}-04 \mathrm{~mol} / \mathrm{l}\end{array}$ & $\begin{array}{l}5.01 \mathrm{e}-03 \mathrm{mg} / \mathrm{ml} ; \\
1.07 \mathrm{e}-05 \mathrm{~mol} / \mathrm{l}\end{array}$ \\
\hline & Class & Poorly soluble & Soluble & Soluble & $\begin{array}{l}\text { Moderately } \\
\text { soluble }\end{array}$ \\
\hline & $\log S($ SILICOS-IT) & -4.28 & -1.94 & -2.07 & -3.79 \\
\hline & Solubility & $\begin{array}{l}2.59 \mathrm{e}-2 \mathrm{mg} / \mathrm{ml} \\
5.31 \mathrm{e}-05 \mathrm{~mol} / \mathrm{l}\end{array}$ & $\begin{array}{c}4.96 \mathrm{e}+00 \mathrm{mg} / \mathrm{ml} \\
1.14 \mathrm{e}-02 \mathrm{~mol} / \mathrm{l}\end{array}$ & $\begin{array}{c}3.71 \mathrm{e}+0 \mathrm{mg} / \mathrm{ml} \\
8.55 \mathrm{e}-3 \mathrm{~mol} / \mathrm{l}\end{array}$ & $\begin{array}{l}7.54 \mathrm{e}-02 \mathrm{mg} / \mathrm{ml} ; \\
1.60 \mathrm{e}-04 \mathrm{~mol} / \mathrm{l}\end{array}$ \\
\hline & Class & $\begin{array}{c}\text { Moderately } \\
\text { soluble }\end{array}$ & Soluble & Soluble & Soluble \\
\hline \multirow{4}{*}{$\begin{array}{l}\text { Medicinal } \\
\text { Chemistry }\end{array}$} & Leadlikeness & $\begin{array}{c}\text { No; } 2 \text { violations: } \\
\text { MW>350, } \\
\text { XLOGP3>3.5 }\end{array}$ & $\begin{array}{l}\text { No; } 1 \text { violation: } \\
\text { MW >350 }\end{array}$ & $\begin{array}{l}\text { No; } 1 \text { violation: } \\
\text { MW>350 }\end{array}$ & $\begin{array}{c}\text { No; } 2 \text { violations: } \\
\text { MW>350, } \\
\text { XLOGP3>3.5 }\end{array}$ \\
\hline & Bioavailability Score & 0.56 & 0.17 & 0.17 & 0.55 \\
\hline & PAINS & 0 alert & $\begin{array}{c}1 \text { alert: } \\
\text { catechol_A }\end{array}$ & 1 alert: catechol_A & 0 alert \\
\hline & Synthetic accessibility & 6.56 & 5.05 & 5.04 & 6.83 \\
\hline
\end{tabular}

Table 4:Toxicity model reports of top four drug candidates 


\begin{tabular}{|c|c|c|c|c|c|}
\hline \multirow{2}{*}{ Classification } & \multirow{2}{*}{ Target } & \multicolumn{4}{|c|}{ Prediction and Probability } \\
\hline & & Asiatic Acid & Aviculerin & Guanjaverin & Witheferin \\
\hline Organ toxicity & Hepatotoxicity & Inactive $(0.91)$ & Inactive $(0.80)$ & Inactive $(0.80)$ & Inactive $(0.93)$ \\
\hline Toxicity end points & Carcinogenicity & Inactive $(0.70)$ & Inactive (0.79) & Inactive $(0.79)$ & Inactive $(0.55)$ \\
\hline Toxicity end points & Immunotoxicity & Active $(0.77)$ & Active (0.68) & Active (0.93) & Active (0.99) \\
\hline Toxicity end points & Mutagenicity & Inactive $(0.81)$ & Inactive $(0.73)$ & Inactive $(0.79)$ & Inactive $(0.79)$ \\
\hline Toxicity end points & Cytotoxicity & Inactive $(0.73)$ & Inactive $(0.72)$ & Inactive (0.69) & Active (0.87) \\
\hline $\begin{array}{l}\text { Tox21-Nuclear } \\
\text { receptor signalling } \\
\text { pathways }\end{array}$ & $\begin{array}{l}\text { Aryl hydrocarbon Receptor } \\
\text { (AhR) }\end{array}$ & Inactive (0.99) & Inactive $(0.85)$ & Inactive $(0.90)$ & Inactive $(0.98)$ \\
\hline $\begin{array}{l}\text { Tox21-Nuclear } \\
\text { receptor signalling } \\
\text { pathways }\end{array}$ & Androgen Receptor (AR) & Inactive $(0.59)$ & Inactive $(0.92)$ & Inactive $(0.96)$ & Inactive $(0.63)$ \\
\hline $\begin{array}{l}\text { Tox21-Nuclear } \\
\text { receptor signalling } \\
\text { pathways }\end{array}$ & $\begin{array}{l}\text { Androgen Receptor Ligand } \\
\text { Binding Domain (AR- } \\
\text { LBD) }\end{array}$ & Inactive $(0.51)$ & Inactive $(0.98)$ & Inactive $(0.97)$ & Inactive $(0.54)$ \\
\hline $\begin{array}{l}\text { Tox21-Nuclear } \\
\text { receptor signalling } \\
\text { pathways }\end{array}$ & Aromatase & Inactive $(0.91)$ & Inactive $(0.98)$ & Inactive $(0.97)$ & Inactive $(0.80)$ \\
\hline $\begin{array}{l}\text { Tox21-Nuclear } \\
\text { receptor signalling } \\
\text { pathways }\end{array}$ & $\begin{array}{l}\text { Estrogen Receptor Alpha } \\
\text { (ER) }\end{array}$ & Inactive $(0.73)$ & Inactive $(0.85)$ & Inactive $(0.92)$ & Inactive $(0.60)$ \\
\hline $\begin{array}{l}\text { Tox21-Nuclear } \\
\text { receptor signalling } \\
\text { pathways }\end{array}$ & $\begin{array}{l}\text { Estrogen Receptor Ligand } \\
\text { Binding Domain (ER- } \\
\text { LBD) }\end{array}$ & Inactive $(0.97)$ & Inactive (0.99) & Inactive $(0.99)$ & Inactive $(0.98)$ \\
\hline $\begin{array}{l}\text { Tox21-Nuclear } \\
\text { receptor signalling } \\
\text { pathways }\end{array}$ & $\begin{array}{l}\text { Peroxisome Proliferator } \\
\text { Activated Receptor } \\
\text { Gamma (PPAR- } \gamma \text { ) }\end{array}$ & Inactive $(0.97)$ & Inactive $(0.93)$ & Inactive $(0.94)$ & Inactive $(0.91)$ \\
\hline $\begin{array}{l}\text { Tox21-Stress } \\
\text { response pathways }\end{array}$ & $\begin{array}{l}\text { Nuclear factor (erythroid- } \\
\text { derived 2)-like } \\
\text { 2/antioxidant responsive } \\
\text { element }\end{array}$ & Inactive (0.89) & Inactive (0.91) & Inactive $(0.94)$ & Inactive $(0.86)$ \\
\hline $\begin{array}{l}\text { Tox21-Stress } \\
\text { response pathways }\end{array}$ & $\begin{array}{l}\text { Heat shock factor response } \\
\text { element (HSE) }\end{array}$ & Inactive $(0.89)$ & Inactive $(0.91)$ & Inactive $(0.94)$ & Inactive $(0.86)$ \\
\hline $\begin{array}{l}\text { Tox21-Stress } \\
\text { response pathways }\end{array}$ & $\begin{array}{l}\text { Mitochondrial Membrane } \\
\text { Potential (MMP) }\end{array}$ & Inactive $(0.85)$ & Inactive (0.89) & Inactive $(0.89)$ & Inactive $(0.80)$ \\
\hline $\begin{array}{l}\text { Tox21-Stress } \\
\text { response pathways }\end{array}$ & $\begin{array}{l}\text { Phosphoprotein (Tumor } \\
\text { Supressor) p53 }\end{array}$ & Inactive $(0.93)$ & Active $(0.55)$ & Inactive $(0.72)$ & Inactive $(0.75)$ \\
\hline $\begin{array}{l}\text { Tox21-Stress } \\
\text { response pathways }\end{array}$ & $\begin{array}{l}\text { ATPase family AAA } \\
\text { domain-containing protein } \\
5 \text { (ATAD5) }\end{array}$ & Inactive $(0.96)$ & Inactive (0.96) & Inactive $(0.96)$ & Inactive $(0.94)$ \\
\hline
\end{tabular}

Table 5: Predicted drug targets for Asiatic acid, Guanjaverin, Aviculerin and Witheferin 


\begin{tabular}{|c|c|c|c|c|c|c|}
\hline $\begin{array}{l}\text { Metab } \\
\text {-olites }\end{array}$ & Drug Targets & Common Name & $\begin{array}{c}\text { Uniprot } \\
\text { ID }\end{array}$ & ChEMBL ID & Target Class & Probability \\
\hline \multirow{6}{*}{ 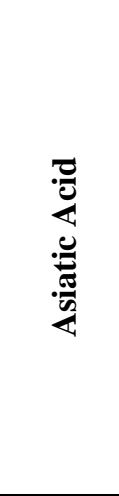 } & $\begin{array}{l}\text { Aldo-keto reductase } \\
\text { family } 1 \text { member B10 }\end{array}$ & AKR1B10 & O60218 & CHEMBL5983 & Enzyme & \\
\hline & $\begin{array}{l}\text { Protein-tyrosine } \\
\text { phosphatase 1B }\end{array}$ & PTPN1 & P18031 & CHEMBL335 & Phosphatase & \\
\hline & $\begin{array}{l}\text { 11- } \beta \text {-hydroxysteroid } \\
\text { dehydrogenase } 1\end{array}$ & HSD11B1 & P28845 & CHEMBL4235 & Enzyme & \\
\hline & DNA polymerase beta & POLB & P06746 & CHEMBL2392 & Enzyme & \\
\hline & $\begin{array}{l}\text { T-cell protein-tyrosine } \\
\text { phosphatase }\end{array}$ & PTPN2 & P17706 & CHEMBL3807 & Phosphatase & \\
\hline & $\begin{array}{l}\text { Phospholipase A2 group } \\
\text { 1B }\end{array}$ & PLA2G1B & P04054 & CHEMBL4426 & Enzyme & \\
\hline \multirow{11}{*}{ 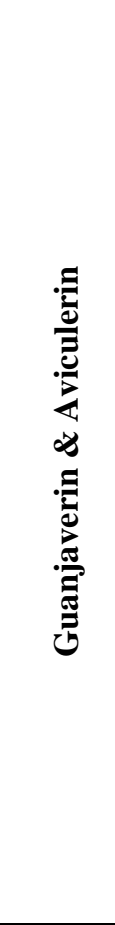 } & Aldose reductase & AKR1B1 & $\mathrm{P} 15121$ & CHEMBL1900 & Enzyme & \\
\hline & Carbonic anhydrase II & $\mathrm{CA} 2$ & P00918 & CHEMBL205 & Lyase & \\
\hline & Carbonic anhydrase VII & CA7 & P43166 & CHEMBL2326 & Lyase & \\
\hline & Carbonic anhydrase XII & CA12 & $\mathrm{O} 43570$ & CHEMBL3242 & Lyase & \\
\hline & Carbonic anhydrase IV & CA4 & $\mathrm{P} 22748$ & CHEMBL3729 & Lyase & \\
\hline & NADPH oxidase 4 & NOX4 & $\begin{array}{l}\text { Q9NPH } \\
5\end{array}$ & $\begin{array}{l}\text { CHEMBL1250 } \\
375\end{array}$ & Enzyme & \\
\hline & $\begin{array}{l}\text { Adrenergic receptor alpha- } \\
2\end{array}$ & ADRA2C & P18825 & CHEMBL1916 & $\begin{array}{l}\text { Family A G } \\
\text { protein-coupled- } \\
\text { receptor }\end{array}$ & \\
\hline & Acetylcholinesterase & ACHE & P22303 & CHEMBL220 & Hydrolase & \\
\hline & Quinone reductase 2 & NQO2 & P16083 & CHEMBL3959 & Enzyme & \\
\hline & $\begin{array}{l}\text { Ribosomal protein S6 } \\
\text { kinase alpha } 3\end{array}$ & RPS6KA3 & P51812 & CHEMBL2345 & Kinase & \\
\hline & Neuromedin-U receptor 2 & NMUR2 & $\begin{array}{l}\text { Q9GZQ } \\
4\end{array}$ & $\begin{array}{l}\text { CHEMBL1075 } \\
144\end{array}$ & $\begin{array}{l}\text { Family A G } \\
\text { protein-coupled } \\
\text { receptor }\end{array}$ & \\
\hline \multirow{11}{*}{ 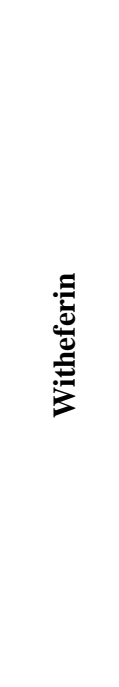 } & Protein kinase $\mathrm{C}$ alpha & PRKCA & P17252 & CHEMBL299 & Kinase & \\
\hline & Cyclooxygenase-2 & PTGS2 & P35354 & CHEMBL230 & Oxidoreductase & \\
\hline & Isoleucyl-tRNA synthetase & IARS & P41252 & CHEMBL3235 & Enzyme & \\
\hline & Protein kinase $\mathrm{C}$ delta & PRKCD & Q05655 & CHEMBL2996 & Kinase & \\
\hline & HMG-CoA reductase & HMGCR & P04035 & CHEMBL402 & Oxidoreductase & \\
\hline & Phosphodiesterase 4D & PDE4D & Q08499 & CHEMBL288 & Phosphodiesterase & \\
\hline & $\begin{array}{l}\text { Telomerase reverse } \\
\text { transcriptase }\end{array}$ & TERT & O14746 & CHEMBL2916 & Enzyme & \\
\hline & Androgen Receptor & AR & P10275 & CHEMBL1871 & Nuclear receptor & \\
\hline & Protein kinase $\mathrm{C}$ epsilon & PRKCE & Q02156 & CHEMBL3582 & Kinase & \\
\hline & Proto-oncogene c-JUN & JUN & P05412 & CHEMBL4977 & Transcription factor & \\
\hline & $\begin{array}{l}\text { Protein-tyrosine phosphatase } \\
\text { 1B }\end{array}$ & PTPN1 & P18031 & CHEMBL335 & Phosphatase & \\
\hline
\end{tabular}

Table 6: Predicted bioactive molecules from drug bank 


\begin{tabular}{|c|c|l|c|l|}
\hline Metabolites & Drug bank id & \multicolumn{1}{|c|}{ Name } & Score & \multicolumn{1}{c|}{ Status } \\
\hline \multirow{5}{*}{ Asiatic acid } & DB00741 & Hydrocortisone & 0.539 & Approved \\
\cline { 2 - 5 } & DB01160 & Dinoprost Tromethamine & 0.529 & Approved \\
\cline { 2 - 5 } & DB07886 & $\begin{array}{l}\text { (11alpha,14beta)-11,17,21- } \\
\text { trihydroxypregn-4-ene-3,20-dione }\end{array}$ & 0.539 & Experimental \\
\cline { 2 - 5 } & DB07209 & $\begin{array}{l}\text { (8R,9Z,12Z)-8-hydroxy-6- } \\
\text { oxooctadeca-9,12-dienoic acid }\end{array}$ & 0.510 & Experimental \\
\hline \multirow{5}{*}{ Guanjaverin } & DB08995 & Diosmin & 0.280 & Approved \\
\cline { 2 - 6 } & DB02375 & Myricetin & 0.236 & Experimental \\
\cline { 2 - 6 } & DB00410 & Mupirocin & 0.481 & Approved \\
\cline { 2 - 6 } & DB00641 & Simvastatin & 0.447 & Approved \\
\cline { 2 - 6 } & DB08224 & $\begin{array}{l}\text { hexahydro-7-methyl-8-[2-[(2r,4r)- } \\
\text { tetrahydro-4-hydroxy-6-oxo-2h-pyran- } \\
\text { 2-yl]ethyl]-1-naphthalenol }\end{array}$ & 0.501 & Experimental \\
\cline { 2 - 6 } Avicularin & DB04775 & Reidispongiolide C & 0.479 & Experimental \\
\cline { 2 - 5 } & DB08995 & Diosmin & 0.249 & Approved \\
\hline
\end{tabular}

Supplementary File 1: Molecular docking results of 27 plant metabolites with different SARS-CoV-2 proteins/protein domains 


\begin{tabular}{|c|c|c|c|c|c|}
\hline Macromolecules & Ligands/Metabolites & Global energy & $\mathrm{ACE}$ & Score & Area \\
\hline \multirow{27}{*}{$\begin{array}{l}\text { Main protease } \\
\text { (6W63) }\end{array}$} & Alicin & -30.25 & -10.73 & 2588 & 335.00 \\
\hline & Andrographolide & -44.40 & -11.85 & 4418 & 461.90 \\
\hline & Apigenin & -42.20 & -12.49 & 3494 & 420.80 \\
\hline & Asiatic acid & -53.05 & -15.26 & 4916 & 577.10 \\
\hline & Avicularin & -48.62 & -18.50 & 4694 & 532.10 \\
\hline & Capsaicin & -41.50 & -12.59 & 4204 & 477.70 \\
\hline & Chavibetol & -26.69 & -8.37 & 2772 & 295.10 \\
\hline & Cinnamic & -23.90 & -6.60 & 2538 & 300.10 \\
\hline & Curcumin & -46.17 & -14.78 & 4812 & 553.70 \\
\hline & Eugenol & -27.26 & -8.65 & 2764 & 307.50 \\
\hline & Flavonoidsarjunone & -39.64 & -12.11 & 4182 & 459.60 \\
\hline & Galangin & -40.62 & -12.12 & 3276 & 407.90 \\
\hline & Gentisic acid & -22.85 & -6.54 & 2282 & 239.10 \\
\hline & Guajaverin & -48.48 & -15.12 & 4450 & 497.50 \\
\hline & Kaempferol & -42.79 & -13.26 & 3712 & 410.10 \\
\hline & Luteolin & -42.28 & -11.85 & 3604 & 414.90 \\
\hline & Mcoumaric acid & -27.51 & -8.43 & 2504 & 279.90 \\
\hline & Piperic acid & -38.57 & -11.17 & 3232 & 371.40 \\
\hline & Piperine & -45.69 & -13.64 & 4528 & 471.80 \\
\hline & Quercetine & -43.15 & -12.56 & 3590 & 418.20 \\
\hline & Swertiamarin & -40.62 & -11.85 & 3896 & 458.10 \\
\hline & Swertinin & -36.99 & -10.87 & 3632 & 433.50 \\
\hline & Thymoquinone & -26.29 & -7.84 & 2800 & 299.30 \\
\hline & Vincamine & -38.56 & -13.65 & 4088 & 526.20 \\
\hline & Vitexin & -44.33 & -13.20 & 4428 & 497.10 \\
\hline & Withaferin & -48.46 & -14.08 & 4984 & 597.40 \\
\hline & Zingiberne & -33.34 & -11.66 & 3508 & 392.10 \\
\hline \multirow{6}{*}{$\begin{array}{l}\text { Nsp9 RNA binding } \\
\text { protein }(6 \mathrm{~W} 4 \mathrm{~B})\end{array}$} & Alicin & -23.37 & -9.07 & 2688 & 317.00 \\
\hline & Andrographolide & -45.51 & -11.45 & 4088 & 564.70 \\
\hline & Apigenin & -35.95 & -9.29 & 3500 & 446.10 \\
\hline & Asiatic acid & -50.04 & -16.37 & 4998 & 564.20 \\
\hline & Avicularin & -39.83 & -235.80 & 4556 & 514.50 \\
\hline & Capsaicin & -35.71 & -11.59 & 4262 & 566.70 \\
\hline
\end{tabular}




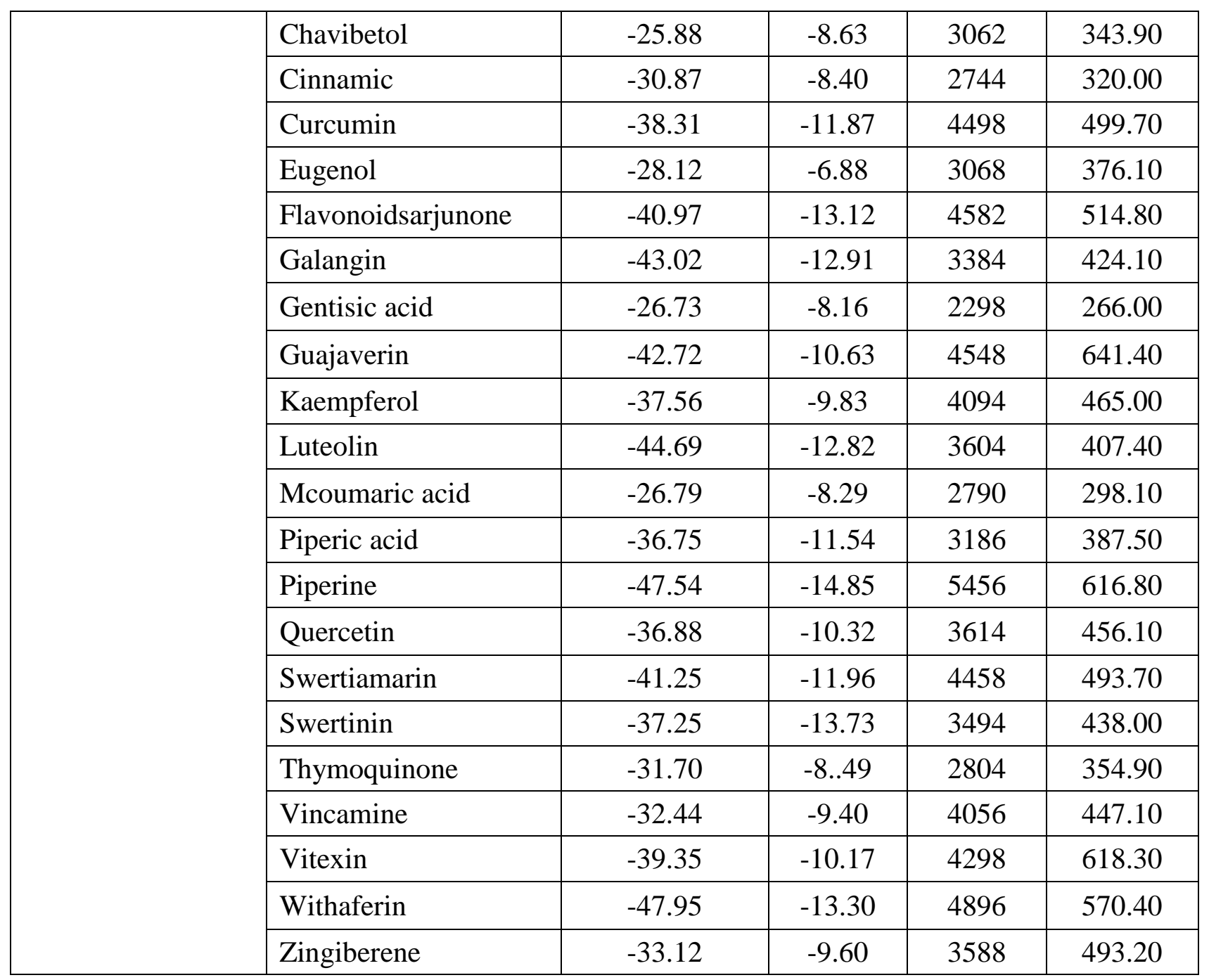

\begin{tabular}{|c|l|c|c|c|c|}
\hline \multirow{2}{*}{$\begin{array}{c}\text { Spike ectodomain } \\
\text { (6VYB) }\end{array}$} & Alicin & -27.25 & -9.68 & 3382 & 373.70 \\
\cline { 2 - 5 } & Andrographolide & -45.37 & -15.44 & 5138 & 656.10 \\
\cline { 2 - 5 } & Apigenin & -43.64 & -13.93 & 3992 & 481.50 \\
\hline
\end{tabular}




\begin{tabular}{|c|c|c|c|c|c|}
\hline & Asiatic acid & -60.68 & -22.33 & 6276 & 771.50 \\
\hline & Avicularin & -52.93 & -17.15 & 5474 & 683.30 \\
\hline & Capsaicin & -45.02 & -11.20 & 5312 & 595.50 \\
\hline & Guajaverin & -55.24 & -17.51 & 5208 & 559.20 \\
\hline & Chavibetol & -26.49 & -8.36 & 3562 & 404.90 \\
\hline & Cinnamic & -28.86 & -7.93 & 3320 & 370.40 \\
\hline & Curcumin & -51.22 & -19.15 & 5498 & 701.80 \\
\hline & Eugenol & -31.95 & -8.67 & 3510 & 403.40 \\
\hline & Flavonoidsarjunone & -47.18 & -16.10 & 5242 & 639.30 \\
\hline & Galangin & -38.87 & -12.21 & 4482 & 512.30 \\
\hline & Gentisic acid & -26.51 & -6.35 & 2842 & 308.50 \\
\hline & Kaempferol & -40.28 & -12.75 & 4336 & 517.10 \\
\hline & Luteolin & -43.23 & -13.67 & 4408 & 523.80 \\
\hline & Mcoumaric acid & -30.38 & -9.56 & 3086 & 363.50 \\
\hline & Piperic acid & -35.99 & -8.74 & 3824 & 447.40 \\
\hline & Piperine & -46.36 & -15.55 & 4770 & 597.80 \\
\hline & Quercetine & -43.18 & -13.59 & 4256 & 507.90 \\
\hline & Swertiamarin & -42.10 & -15.05 & 4822 & 565.40 \\
\hline & Swertinin & -38.75 & -12.81 & 4262 & 532.30 \\
\hline & Thymoquinine & -30.45 & -10.06 & 3418 & 398.70 \\
\hline & Vincamine & -51.86 & -17.31 & 5160 & 650.10 \\
\hline & Vitexin & -46.25 & -16.25 & 5028 & 669.00 \\
\hline & Withaferin & -60.19 & -20.49 & 5760 & 793.10 \\
\hline & Zingiberene & -32.99 & -8.48 & 4436 & 489.20 \\
\hline \multirow{10}{*}{$\begin{array}{l}\text { HR2 Domain } \\
\quad(6 \mathrm{LVN})\end{array}$} & Allicin & -20.47 & -8.64 & 2164 & 259.40 \\
\hline & Andrographolide & -20.77 & -0.89 & 3640 & 395.00 \\
\hline & Apigenin & -23.85 & -8.57 & 3028 & 384.40 \\
\hline & Asiatic acid & -27.58 & -1.12 & 4366 & 500.30 \\
\hline & Avicularin & -26.48 & -1.22 & 3986 & 465.10 \\
\hline & Capsaicin & -21.84 & -1.23 & 3362 & 361.50 \\
\hline & Chavibetol & -15.00 & -2.47 & 2104 & 254.70 \\
\hline & Cinnamic & -17.36 & -6.08 & 2080 & 232.60 \\
\hline & Curcumin & -21.32 & 1.33 & 4458 & 540.00 \\
\hline & Eugenol & -19.49 & -7.02 & 2392 & 275.80 \\
\hline
\end{tabular}




\begin{tabular}{|c|c|c|c|c|c|}
\hline & $\begin{array}{l}\text { Flavonoids } \\
\text { (arjunone) }\end{array}$ & -17.71 & 1.90 & 4122 & 467.10 \\
\hline & Galangin & -21.97 & 0.21 & 3242 & 338.00 \\
\hline & Gentisic acid & -16.43 & -4.95 & 1924 & 200.40 \\
\hline & Guajaverin & -28.73 & -2.13 & 3696 & 443.50 \\
\hline & Kaempferol & -18.68 & -7.45 & 3114 & 387.40 \\
\hline & Luteolin & -22.77 & -1.23 & 2966 & 309.40 \\
\hline & M-coumaric acid & -19.79 & -6.26 & 2070 & 244.60 \\
\hline & Piperic acid & -22.49 & -7.06 & 2664 & 309.50 \\
\hline & Piperine & -23.52 & 0.42 & 3390 & 381.50 \\
\hline & Quercetine & -21.16 & -4.54 & 2892 & 377.50 \\
\hline & Swertiamarin & -21.47 & 1.84 & 3538 & 426.30 \\
\hline & Swertinin & -18.60 & 0.71 & 3304 & 367.70 \\
\hline & Thymoquinone & -19.94 & -6.76 & 2310 & 239.10 \\
\hline & Vincamine & -20.94 & -1.78 & 3728 & 410.40 \\
\hline & Vitexin & -24.76 & -1.95 & 3502 & 424.90 \\
\hline & Withaferin & -28.11 & -1.24 & 4376 & 507.70 \\
\hline & Zingiberene & -19.52 & -2.19 & 3054 & 315.20 \\
\hline \multirow{13}{*}{$\begin{array}{l}\text { Spike receptor } \\
\text { binding domain } \\
\quad(6 \mathrm{M} 0 \mathrm{~J})\end{array}$} & Allicin & -29.23 & -10.78 & 2906 & 331.60 \\
\hline & Andrographolide & -40.95 & -10.29 & 4296 & 574.70 \\
\hline & Apigenin & -38.49 & -10.17 & 3702 & 449.80 \\
\hline & Asiatic acid & -45.69 & -13.09 & 5978 & 691.70 \\
\hline & Avicularin & -43.13 & -11.09 & 5232 & 604.20 \\
\hline & Capsaicin & -44.98 & -12.05 & 4486 & 586.30 \\
\hline & Chavibetol & -30.95 & -8.48 & 3092 & 352.90 \\
\hline & Cinnamic & -29.28 & -7.79 & 2840 & 330.70 \\
\hline & Curcumin & -38.94 & -8.36 & 4762 & 643.80 \\
\hline & Eugenol & -33.32 & -8.49 & 3112 & 398.00 \\
\hline & $\begin{array}{l}\text { Flavonoids } \\
\text { (arjunone) }\end{array}$ & -38.98 & -9.07 & 4768 & 583.60 \\
\hline & Galangin & -36.69 & -9.74 & 3812 & 510.40 \\
\hline & Gentisic acid & -26.77 & -7.29 & 2558 & 297.60 \\
\hline
\end{tabular}




\begin{tabular}{|c|c|c|c|c|c|}
\hline & Guajaverin & -47.34 & -11.22 & 4554 & 575.60 \\
\hline & Kaempferol & -40.20 & -9.03 & 3780 & 496.30 \\
\hline & Luteolin & -37.14 & -9.81 & 3904 & 500.00 \\
\hline & M-coumaric acid & -28.83 & -8.38 & 2852 & 335.60 \\
\hline & Piperic acid & -35.63 & -9.58 & 3472 & 474.00 \\
\hline & Piperine & -39.93 & -10.23 & 4648 & 525.30 \\
\hline & Quercetine & -39.48 & -9.25 & 3712 & 436.70 \\
\hline & Swertiamarin & -44.70 & -10.76 & 4424 & 574.30 \\
\hline & Swertinin & -37.27 & -4.09 & 3708 & 513.80 \\
\hline & Thymoquinone & -28.72 & -6.78 & 2970 & 403.80 \\
\hline & Vincamine & -41.52 & -11.33 & 4480 & 553.20 \\
\hline & Vitexin & -45.02 & -10.31 & 4698 & 569.50 \\
\hline & Withaferin & -46.84 & -11.13 & 5598 & 640.50 \\
\hline & Zingiberene & -29.16 & -7.75 & 3748 & 510.80 \\
\hline \multirow{17}{*}{$\begin{array}{l}\text { Main protease } \\
\quad \text { (6LU7) }\end{array}$} & Allicin & -28.12 & -11.49 & 2746 & 338.40 \\
\hline & Andrographolide & -48.24 & -12.61 & 3838 & 504.40 \\
\hline & Apigenin & -41.45 & -11.28 & 3792 & 421.00 \\
\hline & Asiatic acid & -43.52 & -13.90 & 5050 & 562.20 \\
\hline & Avicularin & -54.04 & -14.77 & 4584 & 520.60 \\
\hline & Capsaicin & -37.56 & -10.50 & 4164 & 497.20 \\
\hline & Chavibetol & -27.05 & -7.71 & 2944 & 312.20 \\
\hline & Cinnamic & -26.59 & -6.92 & 2440 & 314.10 \\
\hline & Curcumin & -50.24 & -14.84 & 5028 & 577.30 \\
\hline & Eugenol & -27.04 & -8.06 & 2872 & 365.00 \\
\hline & $\begin{array}{l}\text { Flavonoids } \\
\text { (arjunone) }\end{array}$ & -38.30 & -10.90 & 4398 & 566.90 \\
\hline & Galangin & -40.07 & -10.95 & 3718 & 415.30 \\
\hline & Gentisic acid & -22.98 & -5.32 & 2272 & 245.80 \\
\hline & Guajaverin & -51.69 & -12.92 & 4182 & 515.50 \\
\hline & Kaempferol & -40.20 & -11.58 & 3492 & 424.30 \\
\hline & Luteolin & -40.06 & -10.58 & 3640 & 423.30 \\
\hline & M-coumaric acid & -28.25 & -7.46 & 2412 & 297.40 \\
\hline
\end{tabular}




\begin{tabular}{|l|l|c|c|c|c|}
\hline & Piperic acid & -33.25 & -9.24 & 3126 & 359.90 \\
\cline { 2 - 6 } & Piperine & -39.80 & -12.30 & 3958 & 480.50 \\
\cline { 2 - 6 } & Quercetine & -44.95 & -12.38 & 3500 & 409.20 \\
\cline { 2 - 6 } & Swertiamarin & -44.00 & -12.24 & 3950 & 490.70 \\
\cline { 2 - 6 } & Swertinin & -38.08 & -10.79 & 4032 & 439.80 \\
\cline { 2 - 6 } & Thymoquinone & -23.55 & -5.84 & 2752 & 358.80 \\
\cline { 2 - 6 } & Vincamine & -40.30 & -12.15 & 4028 & 485.90 \\
\cline { 2 - 6 } & Vitexin & -53.19 & -14.69 & 4786 & 536.10 \\
\cline { 2 - 6 } & Withaferin & -47.08 & -14.06 & 4708 & 560.60 \\
\cline { 2 - 5 } & Zingiberene & -27.93 & -8.25 & 3548 & 381.60 \\
\hline
\end{tabular}

